\title{
Architecture and development of olivocerebellar circuit topography
}

\author{
Stacey L. Reeber ${ }^{1,2}$, Joshua J. White ${ }^{1,2}$, Nicholas A. George-Jones ${ }^{1,2}$ and Roy V. Sillitoe ${ }^{1,2 *}$ \\ Department of Pathology and Immunology, Baylor College of Medicine, Jan and Dan Duncan Neurological Research Institute of Texas Children's Hospital, \\ Houston, TX, USA \\ 2 Department of Neuroscience, Baylor College of Medicine, Jan and Dan Duncan Neurological Research Institute of Texas Children's Hospital, Houston, TX, USA
}

\section{Edited by:}

Chris I. De Zeeuw, Erasmus MC Netherlands

Reviewed by:

Edward S. Ruthazer, Montreal Neurological Institute, Canada Iris Salecker, MRC National Institute for Medical Research, UK

\section{*Correspondence:}

Roy V. Sillitoe, Department of Pathology and Immunology, Baylor College of Medicine, Jan and Dan Duncan Neurological Research Institute of Texas Children's Hospital, 1250 Moursund Street, Suite 1325, Houston, TX 77030 , USA.

e-mail: sillitoe@bcm.edu
The cerebellum has a simple tri-laminar structure that is comprised of relatively few cell types. Yet, its internal micro-circuitry is anatomically, biochemically, and functionally complex. The most striking feature of cerebellar circuit complexity is its compartmentalized topography. Each cell type within the cerebellar cortex is organized into an exquisite map; molecular expression patterns, dendrite projections, and axon terminal fields divide the medial-lateral axis of the cerebellum into topographic sagittal zones. Here, we discuss the mechanisms that establish zones and highlight how gene expression and neural activity contribute to cerebellar pattern formation. We focus on the olivocerebellar system because its developmental mechanisms are becoming clear, its topographic termination patterns are very precise, and its contribution to zonal function is debated. This review deconstructs the architecture and development of the olivocerebellar pathway to provide an update on how brain circuit maps form and function.

Keywords: inferior olive, circuitry, topography, climbing fibers, cerebellum, zones

\section{INTRODUCTION}

It is well established that brain circuits are organized into spatial maps that control behavior (Hubel and Wiesel, 1979; Johnston, 1989; Friedman and O’Leary, 1996; Logan et al., 1996; Bozza et al., 2002; Huffman and Cramer, 2007; Leergaard and Bjaalie, 2007; Li and Crair, 2011; Suzuki et al., 2012). Yet, we have a limited understanding of how precise functional connections form during map development. Neural circuit connectivity is intensely studied in the cerebellum because its cellular networks are well understood and its developmental mechanisms are experimentally tractable. Cerebellar circuits have an established role in motor control and they are now also implicated in higher order functions such as cognition and emotion (Sacchetti et al., 2009; Strata et al., 2011). Two main types of afferents transmit information to the cerebellum: climbing fibers and mossy fibers. Climbing fibers arise only from neurons of the inferior olivary nucleus in the brainstem (Figure 1) and monoinnervate adult Purkinje cells (Figure 2A) whereas mossy fibers originate from numerous brain and spinal cord nuclei to innervate granule cells. Each climbing fiber elicits powerful Purkinje cell responses that sculpt cerebellar function (Figures 2C,D). Here, we discuss the development, organization, and function of the olivocerebellar projection and highlight the mechanisms that make this pathway an attractive model for understanding topographic brain circuitry.

\section{CEREBELLAR SAGITTAL ZONES}

The adult cerebellum is anatomically divided into distinct folds called lobules (Figure 3A; Larsell, 1952). Mammals and birds have 10 lobules that are separated from one another by a series of fissures. Because each fissure extends to a specific depth in the cerebellum, each lobule develops with a unique shape (Figure 3A). The invariance of lobule structure and their conservation across species support the idea that lobule/fissure formation is spatially and temporally controlled by complex morphogenetic programs (Sudarov and Joyner, 2007).

Strikingly, each lobule in the cerebellum is further compartmentalized along the medial-lateral axis into sagittal zones (Figure 3). Each set of zones is clearly delineated by the patterned expression of genes and proteins (Apps and Hawkes, 2009). The most comprehensively studied zonal marker is zebrin II (Brochu et al., 1990; Figures 3B,C, 4D), an antigen on the aldolase C protein (Ahn et al., 1994; Hawkes and Herrup, 1995). Zebrin II is expressed by alternating subsets of Purkinje cells (zebrin II+ adjacent to zebrin $\mathrm{II}-$ ), thus forming complementary rows of biochemically distinct Purkinje cells (Figures 3B,C, 4D). The zonal organization of zebrin II is symmetrical about the cerebellar midline, highly reproducible between individuals, and conserved across species (Brochu et al., 1990; Sillitoe et al., 2005; Apps and Hawkes, 2009). The pattern of zebrin II has an intricate relationship to the expression of several other Purkinje cell proteins. For example, phospholipase C $\beta 3$ (PLC $\beta 3$ ), sphingosine kinase 1a (SPHK1a), and excitatory amino-acid transporter 4 (EAAT4; Hawkes et al., 1985; Hawkes and Leclerc, 1987; Dehnes et al., 1998; Terada et al., 2004; Sarna et al., 2006) are all coexpressed with zebrin II. In contrast, phospholipase C $\beta 4$ (PLC $\beta 4$; Armstrong and Hawkes, 2000; Sarna et al., 2006) is expressed selectively in zebrin II- zones. In addition to the complementary and corresponding relationships between zones, proteins such as neurofilament heavy chain (NFH) divide individual zebrin II zones into smaller sagittal units (Demilly et al., 2011). 


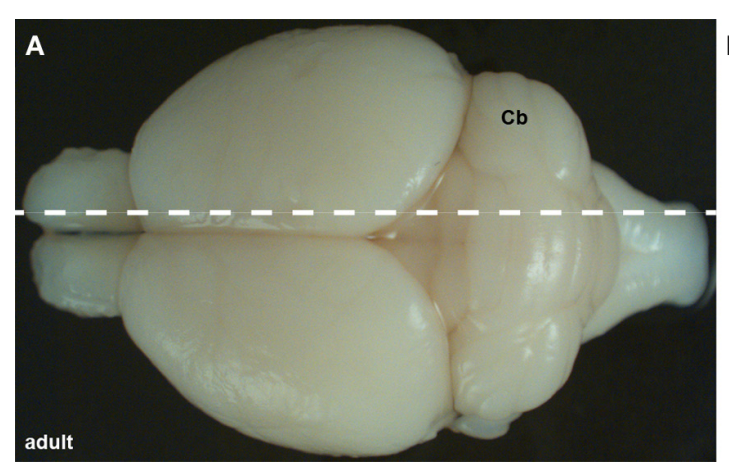

B

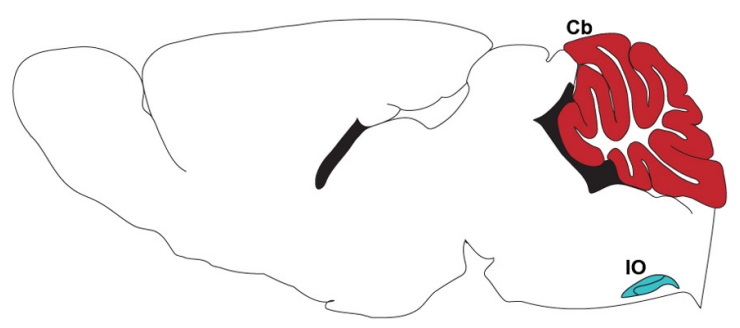

adult

FIGURE 1 | (A) Wholemount image of an adult brain showing the cerebellum (Cb) from a dorsal view. The dotted line indicates the level of the tissue section schematic in (B). (B) Schematic of sagittal section cut through an adult cerebellum showing the cerebellum (red) and inferior olive (IO; blue).

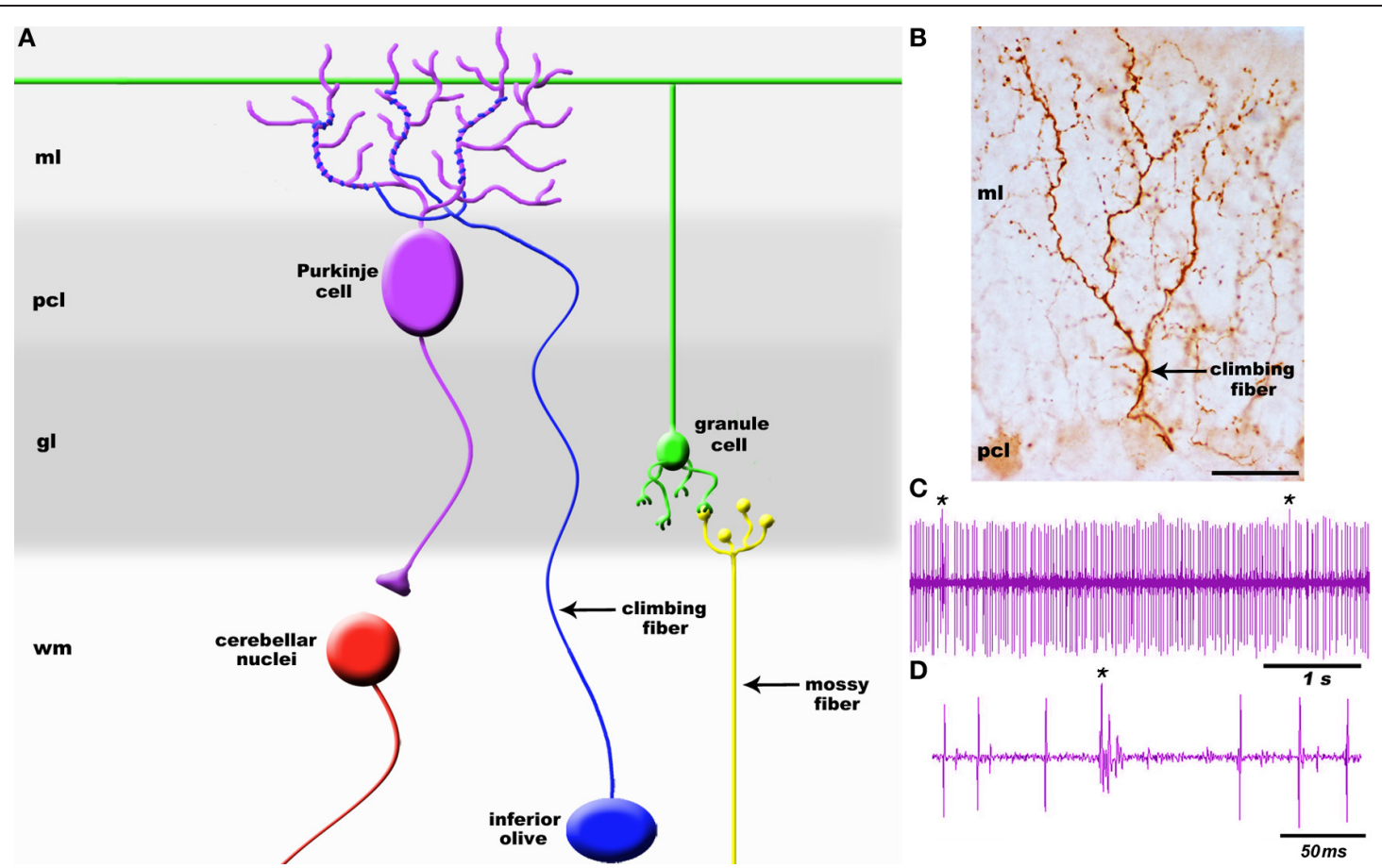

FIGURE 2 | (A) Schematic of a simplified cerebellar microcircuit illustrating the two major sensory afferent pathways that project to the cerebellum: climbing fibers and mossy fibers. Climbing fibers (blue projection) terminate directly onto Purkinje cells whereas mossy fibers (yellow projection) terminate on granule cell dendrites (green). Granule cell axons called parallel fibers contact Purkinje cells (purple). Purkinje cells are the sole output of the cerebellar cortex and transmit signals to the cerebellar nuclei (red). (B) High power image of a climbing fiber expressing cocaine-and amphetamine-regulated transcript (CART) peptide [arrow; staining was performed according to Reeber and Sillitoe (2011)]. The target Purkinje cell is weakly immunoreactive for CART. (C) Example Purkinje cell spike train recorded in vivo. Recordings were performed in Ketamine/Xylazine anesthetized mice using 2-5 M Ohm Tungsten electrodes (Thomas Recording, Germany). Signals were band-pass filtered at $300-5000 \mathrm{~Hz}$, amplified with an ELC-03XS amplifier (NPI, Germany), and recorded with Spike2 (CED, England). (D) Higher power view of the recording trace illustrating the clear distinction between a climbing fiber complex spike (cs) and simple spike (ss) responses in Purkinje cells. Asterisk in panel (C) indicates a complex spike. The layers of the cerebellum are indicated as molecular layer (ml), Purkinje cell layer (pcl), granular layer ( $\mathrm{gl})$, and white matter (wm). The cerebellar nuclei are located in the white matter. Scale bar in $(B)=25 \mu \mathrm{m}$.
Cumulatively, molecularly defined zonal compartments divide the cerebellar cortex into hundreds of reproducible units with each one containing up to several hundred Purkinje cells (Apps and Hawkes, 2009).

Purkinje cell zones may be used to divide the cerebellum into four transverse domains in the anterior-posterior axis (Ozol et al.,
1999). For example, in the vermis zebrin II expression reveals a specific pattern in lobules I-V and VIII/IX (Figures 3B,C, 4D). In contrast, expression of the small $25 \mathrm{kDa}$ heat shock protein HSP25 delineates distinct zonal patterns in lobules VI/VII and IX/X, which express zebrin II in all Purkinje cells (Armstrong et al., 2000). Afferent termination patterns mirror the topography 

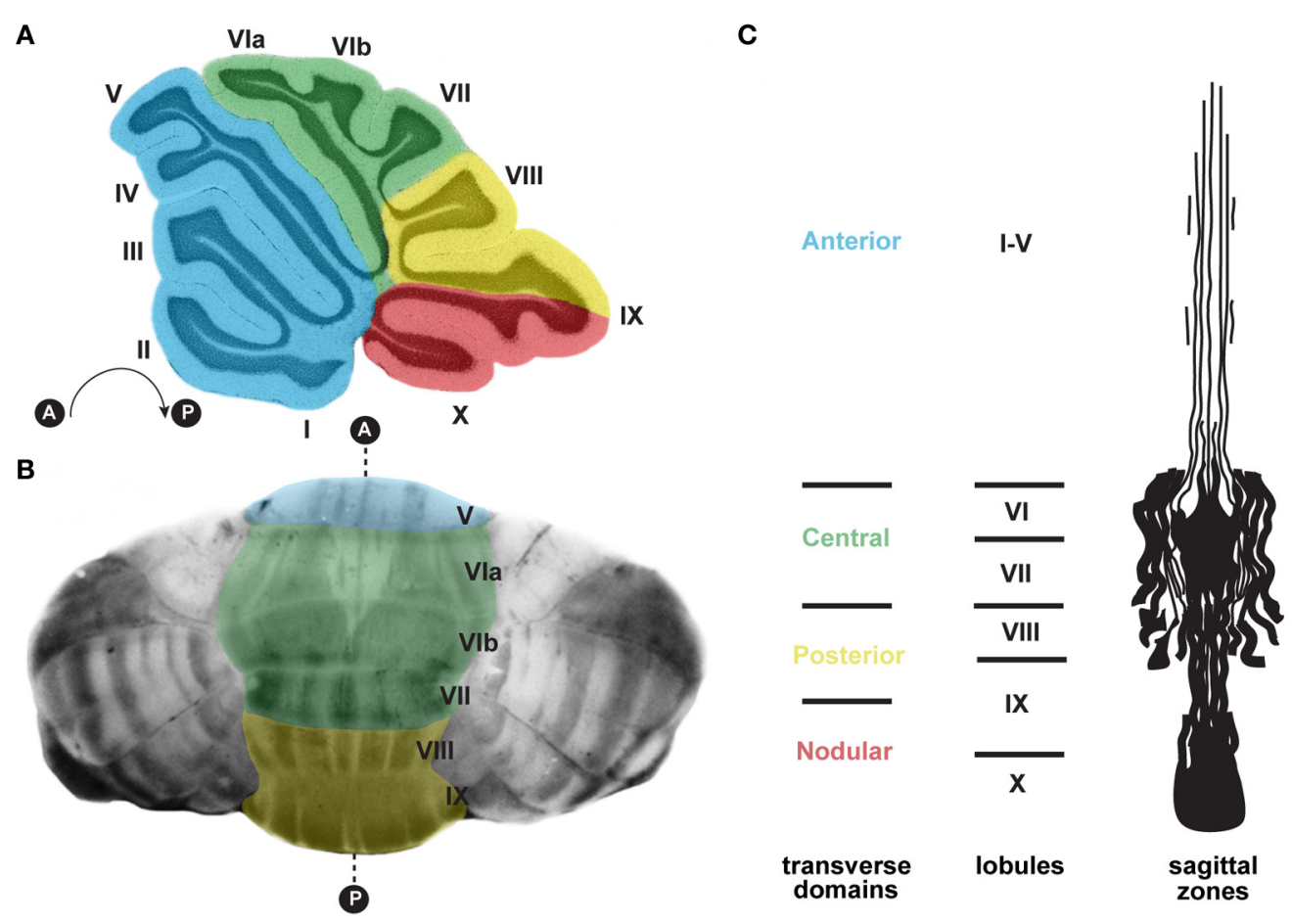

FIGURE 3 | (A) Schematic of a sagittal section cut through the cerebellar vermis revealing the stereotypical foliation pattern, which consists of 10 lobules [adapted with permission from White and Sillitoe (2013)]. The cerebellum can be further divided along the anterior-posterior axis into four transverse domains: anterior (blue; lobules I-V), central (green; lobules VI and VII), posterior (yellow; lobules VIII and anterior IX), and nodular (red; lobules posterior IX and X) (Ozol et al., 1999). (B) In the adult cerebellum, zebrin II/aldolase $\mathrm{C}$ expression, which is revealed using wholemount staining (Sillitoe and Hawkes, 2002; White et al., 2012), delineates zones of Purkinje cells. The transverse zones are color coded according to panel (A). (C) A schematic representation of an unfolded vermis illustrating the full pattern of zebrin II zones (adapted with permission from Sillitoe and Joyner, 2007). Lobule numbers are indicated by Roman numerals. Anterior and posterior axes are denoted by $A$ and $P$. of Purkinje cell zones (Figures 4B,E). As a result, each transverse domain is innervated by a specific combination of functionally distinct afferent fibers. For instance, spinocerebellar mossy fibers project to lobules I-V and VIII/IX (Arsenio Nunes and Sotelo, 1985; Brochu et al., 1990; Sillitoe et al., 2010), whereas the vestibulocerellar mossy fibers project mainly to lobules IX and X (Jaarsma et al., 1997; Maklad and Fritzsch, 2003). In mouse, climbing fibers that express cocaine- and amphetamine-related transcript peptide (CART) terminate selectively in lobules VI/VII and IX/X (Reeber and Sillitoe, 2011), and corticotrophin releasing factor (CRF) expressing climbing fibers are expressed in a striking array of zones in lobules I-V and VIII/IX (Figures 4C,E) (Sawada et al., 2008).

The efferent side of the cortical circuit also respects the zonal topography. Sugihara and collaborators have mapped the trajectories of Purkinje cell axons from specific cerebellar cortical compartments onto the three sets of cerebellar nuclei. They revealed a close correspondence between adolase $\mathrm{C}$ expressing Purkinje cell terminals with subdivisions of cerebellar nuclei (Sugihara and Shinoda, 2007). Together, Purkinje cell zones, afferent topography, and Purkinje cell efferent projections to the cerebellar nuclei define the cerebellar module, the functional unit of the cerebellum (Apps and Hawkes, 2009; Ruigrok, 2011).

\section{ANATOMICAL AND FUNCTIONAL ORGANIZATION OF OLIVOCEREBELLAR ZONES}

Fine topological mapping using anterograde tracers injected into specific sub-nuclei of the inferior olive and the tracing of climbing fiber collateral projections labeled from injections into the cerebellar cortex of birds, rodents, and primates have shown that there is a strict and precise association between climbing fiber topography and zebrin II Purkinje cell zones (Voogd et al., 2003; Sugihara and Shinoda, 2004; Voogd and Ruigrok, 2004; Sugihara and Quy, 2007; Pakan and Wylie, 2008; Sugihara et al., 2009; Fujita et al., 2010). In addition, several studies have used climbing fiber markers to link the architecture of chemically distinct subsets of climbing fiber afferents to the adult pattern of Purkinje cell zones (Table 1). For example, CRF, an amino acid peptide, is expressed in a subset of climbing fibers that corresponds to specific Purkinje cell zones (Sawada et al., 2001, 2008) (Figures 4C,E). In addition, we recently showed that the expression of the CART 55-102 peptide (Figure 2B) is intricately patterned into a complex topographic map that respects HSP25 (mouse) and zebrin II (rat) Purkinje cell zone boundaries (Reeber and Sillitoe, 2011). The class III intermediate filament protein peripherin is also expressed in a subset of climbing fibers that are organized into parasagittal compartments, although it is not clear how peripherin labeled climbing fibers relate to Purkinje 


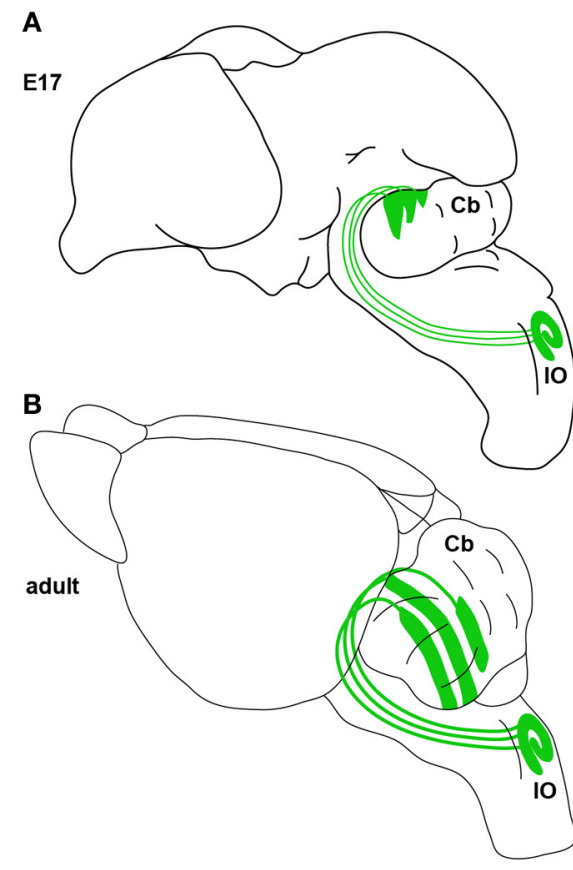

FIGURE 4 | (A) Schematic illustrating climbing fibers projecting from the inferior olivary nucleus $(\mathrm{IO})$ to the cerebellum $(\mathrm{Cb})$ and their organization into a crude zonal pattern at E17. (B) A schematic of the adult brain showing climbing fibers projecting from the inferior olive $(\mathrm{IO})$ to well-defined Purkinje cell zones in the cerebellum. (C-E) In the adult cerebellum corticotropin-releasing factor (CRF) is expressed in subsets of climbing fibers that align with zebrin II
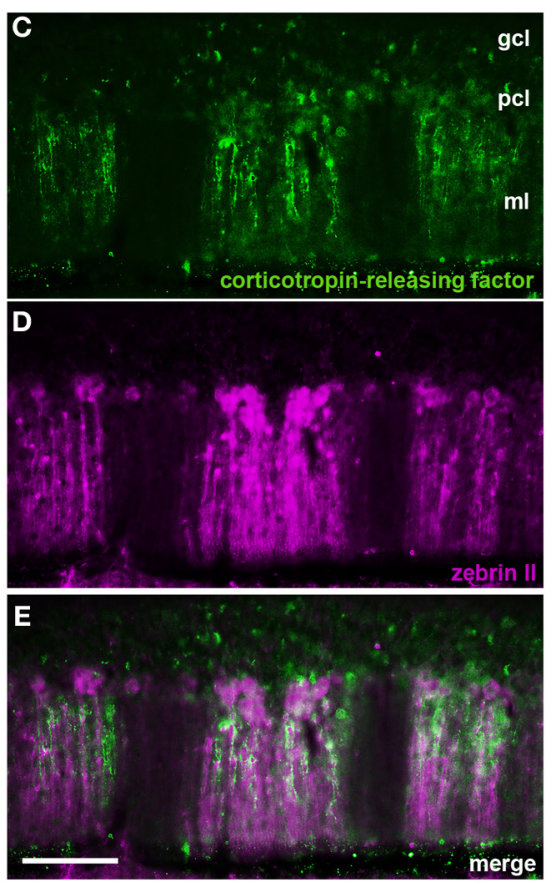

Purkinje cell zones. Panels (C) and (D) show individual channels of CRF and zebrin II expression and panel (E) is a merged image showing the corresponding relationship between the two patterns. The staining pattern of CRF and its relationship to zebrin II zones was previously described (Sawada et al., 2008). CRF and zebrin II staining was carried out exactly as previously described (Sawada et al., 2008). Scale bar in (E) $=100 \mu \mathrm{m}$ (applies to C-D). cell zones (Errante et al., 1998). The precise topography of the olivocerebellar pathway raises the tantalizing possibility that zonal circuits may be functionally relevant. In this regard, two pressing questions have yet to be fully answered: (1) what is the functional significance of zones? and (2) what role do topographic circuits play during behavior?

Previous electrophysiological mapping studies suggested that parasagittal zones could be related to cerebellar function (Armstrong et al., 1974; Ekerot and Larson, 1980; Llinas and Sasaki, 1989; Chockkan and Hawkes, 1994; Sugihara et al., 1995; Chen et al., 1996; Hallem et al., 1999). However, it was only recently that modern optical imaging and electrophysiological approaches were exploited to uncover potential links between functional cerebellar circuits and zonal architecture (Ebner et al., 2012; Graham and Wylie, 2012). In their seminal paper, Wadiche and Jahr (2005) used molecular physiology approaches to demonstrate that synaptic plasticity may vary between zones. Accordingly, the level of glutamate that is released at climbing fiber terminals is zone dependent (Paukert et al., 2010) and climbing fiber inputs initiate synchronous firing in zones of Purkinje cells (Sasaki et al., 1989; Lang et al., 1999; Blenkinsop and Lang, 2006; Wise et al., 2010). These studies support the notion that there are fundamental differences in the physiology of Purkinje cell zones and suggest the possibility that climbing fibers contribute to the functional specificity of the zones.
The behavioral significance of zones remains elusive. However, surgically induced lesions and localized delivery of pharmacological agents into the inferior olive have provided some evidence that cerebellar zones may facilitate behavior (Watanabe et al., 1997; Seoane et al., 2005; Pijpers et al., 2008; Horn et al., 2010; Cerminara and Apps, 2011). For example, Llinas and collaborators found that when the neurotoxin 3-acetylpyridine (3AP) is injected intraperitoneally, the inferior olive is rapidly destroyed and severe ataxia emerges (Llinas et al., 1975). Similarly, injecting another neurotoxin called trans-crotononitrile (TCN) into rats inactivates the olive and induces profound motor deficits (Seoane et al., 2005; Cerminara and Apps, 2011). Ruigrok and colleagues used yet a different approach to inactivate the olive (Pijpers et al., 2008). They injected cholera toxin b conjugated to saporin into individual cerebellar cortical zones, which retrogradely transported the neurotoxin into the olive and induced dysfunction of specific modules. By targeting distinct modules they were able to demonstrated specific defects in the step phase-dependent modulation of cutaneously induced reflexes during locomotion (Pijpers et al., 2008; Cerminara and Apps, 2011). Moreover, inactivating specific olivary subdivisions in cats with the glutamate receptor blocker, CNQX, produced a series of unique motor deficits that were dependent on the particular sub-nucleus that was lesioned (Cerminara, 2010; Horn et al., 2010). What is far from clear is whether each zone encodes specific behaviors (or distinct aspects of a behavior), or 


\section{Table 1 | Molecular and genetic markers for studying olivocerebellar topography.}

\begin{tabular}{ll}
\hline Transient expression in subsets of climbing fibers \\
\hline CGRP (zones in rat E16-P20) & Chedotal and Sotelo, 1992; \\
& Morara et al., 1992 \\
Parvalbumin (zones in rat $\sim$ P0-P10) & Wassef et al., 1992; \\
& Chedotal and Sotelo, 1993
\end{tabular}

Topographic climbing fiber projections

\begin{tabular}{ll}
\hline Calretinin (zones in cat) & Yan and Garey, 1996 \\
CART (zones in mouse and rat) & Reeber and Sillitoe, 2011 \\
CRF (zones in mouse and opossum) & Cummings et al., 1989; \\
& Sawada et al., 2008 \\
DNPINGLUT2 (zones in mouse) & Paukert et al., 2010 \\
NPY (zones in rat) & Ueyama et al., 1994 \\
Peripherin (zones in rat) & Errante et al., 1998 \\
\hline
\end{tabular}

\section{Compartmentalization of the inferior olive}

\begin{tabular}{|c|c|}
\hline BEN & Chedotal et al., 1996 \\
\hline Brn3a & Xiang et al., 1996 \\
\hline Brn3b & Xiang et al., 1996 \\
\hline CART & Reeber and Sillitoe, 2011 \\
\hline Cdh6 & Suzuki et al., 1997 \\
\hline Cdh8 & $\begin{array}{l}\text { Suzuki et al., 1997; Redies } \\
\text { et al., } 2011\end{array}$ \\
\hline Cdh 11 & Suzuki et al., 1997 \\
\hline CRF & Yamano and Tohyama, 1994 \\
\hline Cx36 & $\begin{array}{l}\text { Belluardo et al., 2000; } \\
\text { Weickert et al., } 2005\end{array}$ \\
\hline$C \times 45$ & Van Der Giessen et al., 2006 \\
\hline Cx47 & Weickert et al., 2005 \\
\hline Cx57 & Zappala et al., 2010 \\
\hline$D C C$ & Bloch-Gallego et al., 1999 \\
\hline EphA3 & Nishida et al., 2002 \\
\hline EPHA4 & Hashimoto et al., 2012 \\
\hline EphA5 & Nishida et al., 2002 \\
\hline EphA6 & Nishida et al., 2002 \\
\hline EPHA7 & Hashimoto et al., 2012 \\
\hline ER81 & $\begin{array}{l}\text { Zhu and Guthrie, 2002; } \\
\text { Hashimoto et al., } 2012\end{array}$ \\
\hline FOXP2 & Hashimoto et al., 2012 \\
\hline NPY & $\begin{array}{l}\text { Ueyama et al., 1994; Morara } \\
\text { et al., } 1997\end{array}$ \\
\hline $\mathrm{Nr}-\mathrm{CAM}$ & Backer et al., 2002 \\
\hline Pannexin1 & Weickert et al., 2005 \\
\hline$P d h 7$ & Redies et al., 2011 \\
\hline Pdh10 & Redies et al., 2011 \\
\hline Unc-5H2 & Bloch-Gallego et al., 1999 \\
\hline Unc-5H3 & Bloch-Gallego et al., 1999 \\
\hline DNPINGLUT2 & Hisano et al., 2002 \\
\hline
\end{tabular}

Genetic markers for the inferior olive and/or climbing fibers

\begin{tabular}{ll}
\hline CART-Cre & Madisen et al., 2010 \\
CRF-Cre & Martin et al., 2010
\end{tabular}

(Continued)
Table 1 | Continued

\begin{tabular}{ll}
\hline Cx36-LacZ & Degen et al., 2004 \\
Cx45-lacZ & Van Der Giessen et al., 2006 \\
Npy-GFP & Nishiyama et al., 2007 \\
Parvalbumin-Cre & Tanahira et al., 2009 \\
Parvalbumin-CreER & Taniguchi et al., 2011
\end{tabular}

Note that the markers in each subsection are organized in alphabetical order and molecules of the same family are grouped together. The names of proteins are upper case and not italicized. mRNAs and transgenic mouse lines are italicized.

whether multiple zones interact during motor control. Perhaps one way to unravel what zones do is to uncover how they form. Indeed, developmental studies have raised two critical questions that are ultimately relevant to cerebellar behavior: (1) what are the cellular and molecular mechanisms that control Purkinje cell zone development? and (2) how do climbing fiber projections invade, recognize, and connect to their targets?

\section{GENETIC LINEAGE, MIGRATION, AND AXONOGENESIS OF INFERIOR OLIVE CELLS}

Several landmark studies have used the regulatory sequences of developmentally expressed genes to design genetic tools for tracking the fate of cerebellar and inferior olive cells from embryogenesis to adulthood (Rodriguez and Dymecki, 2000; Hoshino et al., 2005; Machold and Fishell, 2005; Pascual et al., 2007). Genetic fate-mapping studies using Atonal homolog 1 (Atoh1, formerly known as Math1) and Wnt1 regulatory elements revealed that inferior olive neurons emerge from a distinct progenitor pool in the lower rhombic lip of the hindbrain (Rodriguez and Dymecki, 2000; Landsberg et al., 2005; Wang et al., 2005; Nichols and Bruce, 2006). In accordance with these findings, genetic fate-mapping using a pancreas specific transcription factor 1a-Cre (Ptfla Cre/+) allele to drive lacZ reporter gene expression in R26R [Gt(ROSA)26Sor ${ }^{\text {tmlsor }}$; Soriano, 1999] mice revealed that inferior olivary neurons are derived from a distinct Ptfla domain (Hoshino et al., 2005; Yamada et al., 2007). Hoshino and colleagues determined that Ptfla is required for the proper development of inferior olive neurons, because the inferior olivary complex is severely altered in Ptfla null mutants (Yamada et al., 2007). Without Ptfla, some inferior olive neurons do not differentiate while others migrate inappropriately. Moreover, a large number of apoptotic cells were observed in the Ptfla mutants, and the fate of Ptfla-dependent lineages adopted mossy fiber neuron characteristics (Yamada et al., 2007). Although Ptfla appears to control the development of most, if not all, olivary neurons, it is not clear what upstream or downstream molecular pathways might be responsible for generating the sub-nuclei. Studies by Bloch-Gallego and colleagues provide some insight into this question. The authors determined that the absence of Rho-guanine exchange factor Trio impairs the organization of the inferior olivary nucleus into distinct lamellae (Backer et al., 2007). Additionally, in a recent elegant study, quail-chick chimaeras were used to provide evidence that each inferior olive sub-nucleus originates from 
specific rhombomeres, developmental hindbrain units that are each restricted in their lineages (Hidalgo-Sanchez et al., 2012). It is intriguing that climbing fiber zones, which arise from distinct olivary sub-nuclei, may be specified early by rhombomere specific cues.

Inferior olive neurons are born dorsally in the lower rhombic lip and migrate circumferentially around the edges of the brainstem to their final location near the ventral midline (Altman and Bayer, 1987; Sotelo, 2004; Sotelo and Chedotal, 2005) (Table 2). Tritiated thymidine labeling (Altman and Bayer, 1987) and HRP axonal tracing in vitro (Bourrat and Sotelo, 1988, 1990b) revealed that inferior olivary neurons migrate along the lateral edges of the brainstem in a unique "submarginal stream" (Altman and Bayer, 1987; Bourrat and Sotelo, 1988, 1990b; Sotelo and Chedotal, 2005). Interestingly, the somata of olivary neurons do not cross the floor plate, whereas their axons do cross and project exclusively to the contralateral cerebellum (Altman and Bayer, 1987; Altman, 1997). The restriction of olivary neurons to one side of the midline is controlled by both chemoattractive and chemorepellent molecules (e.g., netrin-1/DCC and Slit/Robo; Bloch-Gallego et al., 1999; Causeret et al., 2002; de Diego et al., 2002; Marillat et al., 2004). Marillat et al. (2004) showed that Rig-1/Robo3 plays an essential role in controlling the migration of precerebellar neurons and the projection of axons across the midline. In Rig1/Robo3 deficient mice, inferior olive neurons incorrectly send axons to the ipsilateral cerebellum in addition to sending the normal contralateral projection (Marillat et al., 2004).

The first climbing fibers arrive in the developing cerebellum at $\sim$ embryonic day (E) $14 / 15$ in the mouse (Paradies and Eisenman, 1993) (Table 2) and are already organized in a crude zonal map at $\sim$ E15/16 (Sotelo et al., 1984; Chedotal and Sotelo, 1992; Paradies and Eisenman, 1993; Paradies et al., 1996), which is approximately when Purkinje cells begin to express parasagittal markers (e.g., engrailed1/2 and L7/Pcp2) (Hashimoto and Mikoshiba, 2003; Wilson et al., 2011). By E17 in mice, olivocerebellar topography strongly corresponds with the nascent architecture of Purkinje cell zones (Paradies et al., 1996; Figure 4A).

\section{FORMATION OF OLIVOCEREBELLAR ZONES}

The almost perfect overlap between climbing fiber terminal field topography and Purkinje cell zones suggests that the spatial and temporal targeting of cerebellar afferent pathways is closely coordinated with Purkinje cell development. Purkinje cells become postmitotic between $\sim$ E10 and $\sim$ E13 and form symmetrical

Table 2 | Timeline of olivocerebellar development.

\begin{tabular}{|c|c|c|}
\hline Developmental stage & Developmental event & References \\
\hline$\sim \mathrm{E} 12 / 13$ rat (E10/11 mouse) & Inferior olive neurons are born & $\begin{array}{l}\text { Pierce, 1973; Bourrat and Sotelo, 1990a, 1991; } \\
\text { Sotelo, } 2004\end{array}$ \\
\hline$\sim \mathrm{E} 14 / 15$ mouse & Climbing fibers arrive in cerebellum & Paradies and Eisenman, 1993 \\
\hline 〜E16-E18 rat (E14-16 mouse) & $\begin{array}{l}\text { Inferior olive neurons settle in final position adjacent to } \\
\text { the floor plate }\end{array}$ & Bourrat and Sotelo, 1990a; Sotelo, 2004 \\
\hline$\sim$ E16 rat (E14 mouse) & $\begin{array}{l}\text { Transient biochemical compartmentation of inferior olive } \\
\text { and Purkinje cells (arising independently) }\end{array}$ & Wassef et al., 1992; Larouche et al., 2006 \\
\hline$\sim$ E15/16 mouse & Climbing fibers organize into crude parasagittal clusters & Paradies and Eisenman, 1993 \\
\hline$\sim$ E17 mouse & $\begin{array}{l}\text { Climbing fiber topography corresponds clearly with } \\
\text { nascent Purkinje cell zone }\end{array}$ & Paradies et al., 1996 \\
\hline PO-P5 rat (P0-P3 mouse) & $\begin{array}{l}\text { Olivocerebellar projections resolve into precise sagittal } \\
\text { zones similar to the adult }\end{array}$ & Sotelo et al., 1984 \\
\hline$\sim P 0$ rat (P0 mouse) & Creeper stage starts & Watanabe and Kano, 2011 \\
\hline P0-P10 rat (P0-P8 mouse) & Critical period for olivocerebellar plasticity & Sherrard et al., 1986 \\
\hline 〜P3 mouse & $\begin{array}{l}\text { Discrete climbing fiber mediated EPSCs recorded in } \\
\text { Purkinje cells (all fibers induce similar amplitudes in } \\
\text { perinatal Purkinje cells) }\end{array}$ & Hashimoto and Kano, 2003 \\
\hline$\sim$ P5 rat (P3 mouse) & Pericellular nest stage starts & Watanabe and Kano, 2011 \\
\hline P5 mouse & Development of climbing fiber terminal structure & Mason and Gregory, 1984 \\
\hline$\sim P 7$ mouse & "Winner" climbing fiber is strengthened & Hashimoto and Kano, 2003 \\
\hline End of the first postnatal week & Climbing fiber complex spikes are first detected & Woodward et al., 1969 \\
\hline$\sim$ P9 rat (P7 mouse) & Capuchon stage & Watanabe and Kano, 2011 \\
\hline 〜P12 rat (P10 mouse) & Dendritic stage commences & Watanabe and Kano, 2011 \\
\hline 〜P7-11 rat (P5-9 mouse) & $\begin{array}{l}\text { Climbing fiber pruning and perisomatic synpase } \\
\text { elimination: the early phase }\end{array}$ & Watanabe and Kano, 2011 \\
\hline 〜P12-17 rat (P10-15 mouse) & $\begin{array}{l}\text { Climbing fiber pruning and perisomatic synpase } \\
\text { elimination: the late phase }\end{array}$ & Watanabe and Kano, 2011 \\
\hline
\end{tabular}


zonal "clusters" by E14 (Hashimoto and Mikoshiba, 2003; Hoshino et al., 2005; Sillitoe et al., 2009; Namba et al., 2011; Sudarov et al., 2011). Climbing fiber neurons are also born at $\sim$ E10/11 (Sugihara and Shinoda, 2007). Interestingly, when they arrive in the developing cerebellum they immediately project into clusters of Purkinje cells (Paradies and Eisenman, 1993). The predictable termination of climbing fibers into Purkinje cell zones suggests that the Purkinje cells may play an active role in instructing the pattern of olivocerebellar targeting.

Sotelo and collaborators postulated that the cerebellum and the inferior olive might have matching gene expression domains that establish bidirectional signaling to generate the olivocerebellar map (Sotelo and Wassef, 1991; Sotelo and Chedotal, 1997, 2005). Support for this hypothesis was first provided by using a combination of markers that labeled zones of Purkinje cells (calbindin, GMP-cyclic dependent protein kinase, Purkinje cellspecific glycoprotein, and PEP-19) and also marked corresponding subsets of inferior olive cells along with their projections [calbindin, parvalbumin, and calcitonin gene-related peptide (CGRP); Table 1]. The precision and reproducibility of zonal boundaries defined by these markers suggested the possibility that inferior olivary neurons might target Purkinje cell zones by recognizing positional cues (Sotelo and Wassef, 1991; Sotelo and Chedotal, 1997, 2005).

Eph/ephrin genes play a major role in establishing brain topography (Flanagan and Vanderhaeghen, 1998; Cang et al., 2008a,b; Allen-Sharpley and Cramer, 2012). In the cerebellum, eph/ephrin are expressed in distinct parasagittal domains (Karam et al., 2000, 2002). Nishida and coworkers (2002) provided compelling evidence for the involvement of eph/ephrin signaling in controlling the molecular matching between climbing fibers and Purkinje cells during olivocerebellar circuit formation (Nishida et al., 2002). They showed that altering ephA receptor and ephrin-A ligand expression in chick hindbrain explant cultures disrupted the anterior-posterior targeting of olivocerebellar axons. However, this study did not address whether eph/ephrin signaling controls the development of olivocerebellar zones (Nishida et al., 2002; Hashimoto and Hibi, 2012). Regardless, because specific ephA/ephrin-A manipulations can disrupt the global targeting of olivocerebellar axons, there is a possibility that other eph/ephrins and/or additional molecules likely cooperate to establish precise Purkinje cell-afferent interactions during map formation. Besides the eph/ephrins, possible candidates are the type-II classic cadherin and $\delta$-protocadherin cell-cell adhesion molecules, which are expressed in a striking array of Purkinje cell sagittal zones (Suzuki et al., 1997; Neudert et al., 2008; Redies et al., 2011) and in specific subdivisions of the inferior olive (Suzuki et al., 1997; Neudert et al., 2008; Redies et al., 2011). Despite these clues, we still do not have a clear picture of what genes control the topographic connectivity of olivocerebellar zones nor do we understand the detailed mechanisms that initiate and maintain the physical interaction between specific Purkinje cells and climbing fibers. However, recent work demonstrates that starting from birth, inferior olive neurons spontaneously organize into clusters that fire synchronous $\mathrm{Ca}^{2+}$ transients in in vitro brain slice preparations (Rekling et al., 2012). Curiously, during early postnatal development spontaneous waves travel along chains of axon collaterals that connect sagittal rows of Purkinje cells (Watt et al., 2009). Both phenomena were suggested as likely mechanisms contributing to the development of cerebellar compartments. However, whether the spontaneous waves of Purkinje cell activity are linked to the spontaneous activity of inferior olive neurons awaits further analysis. It will also be interesting to determine whether cerebellar spontaneous activity interacts with developmental gene function in a zone specific fashion.

\section{POSTNATAL REMODELING OF CLIMBING FIBERS}

Following the establishment of the crude zonal map, climbing fibers undergo extensive morphological changes and proceed through different stages of fiber remodeling to form functionally mature connections (Watanabe and Kano, 2011) (Table 2). The first phase of remodeling is the "creeper" stage $(\sim \mathrm{P} 0$ in rat) when climbing fibers are very thin and form transient synapses on immature Purkinje cell dendrites (Chedotal and Sotelo, 1993; Sugihara, 2005; Watanabe and Kano, 2011). Then, climbing fibers enter a "transitional" stage and exhibit characteristics that are intermediate between those of the creeper and nest stages (Sugihara, 2005). The "pericellular nest' stage ( $\sim$ P5) is defined by the dense terminal arbors ("nest") that surround Purkinje cell somata (Cajal, 1911; O'Leary et al., 1971; Mason et al., 1990; Sugihara, 2005; Watanabe and Kano, 2011). During this stage, each Purkinje cell receives polyneuronal input from more than five different climbing fibers. Climbing fibers are progressively displaced onto the developing dendritic stems of maturing Purkinje cells ("capuchon stage"; starting at $\sim \mathrm{P9}$ ). As the dendritic arbors develop, the climbing fibers leave their perisomatic and capuchon positions to occupy peridendritic positions (after $\sim$ P12; referred to as dendritic stage; Chedotal and Sotelo, 1992; Watanabe and Kano, 2011). During this period, climbing fibers translocate up the Purkinje cell dendrite to find their ultimate location within the basal two thirds of the molecular layer (Crepel et al., 1976; Mariani and Changeux, 1981; Hashimoto and Kano, 2005; Kano and Hashimoto, 2009; Watanabe and Kano, 2011).

The monoinnervation of adult climbing fibers onto Purkinje cells is achieved through massive pruning of climbing fibers during postnatal development. Previous studies have revealed systematic changes occurring in the relative synaptic strength of multiple climbing fibers when they polyinnervate a single Purkinje cell during postnatal development. These studies revealed that climbing fiber mediated excitatory postsynaptic currents (EPSCs) recorded in Purkinje cells have similar amplitudes until $\sim \mathrm{P} 3$. In the second postnatal week, multiple EPSCs differentiate into one large EPSC and a few small EPSCs (Hashimoto and Kano, 2003). These results suggest that climbing fiber synaptic strengths are similar to one another during early postnatal development, and a single climbing fiber, the "winner," is selectively strengthened during the second postnatal week ( P7; Hashimoto and Kano, 2003; Bosman et al., 2008). Following these studies, Kano and colleagues used electrophysiological and morphological techniques to determine that competition between multiple climbing fibers occurs at the soma before climbing fibers form synapses with Purkinje cell dendrites (Hashimoto et al., 2009). Notably, the "winner" climbing fiber undergoes translocation to the dendrites 
and simultaneously maintains synapses on the soma, while the weaker climbing fibers remain around the soma forming "pericellular nests" with the "winner" synapses (Hashimoto et al., 2009). After the strengthening of a single "winner" climbing fiber, pruning and perisomatic synapse elimination occur in two distinct phases: the early phase ( $\sim \mathrm{P} 7-11)$, which is independent of parallel fiber synapses and the late phase $(\sim \mathrm{P} 12-17)$, which depends on activity between parallel fibers and Purkinje cells (Watanabe and Kano, 2011).

In three different mutant mice, weaver, staggerer, and reeler, Purkinje cells develop in the absence of granule cells but are permanently innervated by multiple climbing fibers (Crepel and Mariani, 1976; Mariani et al., 1977; Crepel et al., 1980; Mariani and Changeux, 1980; Steinmayr et al., 1998). Similarly, studies using experimentally-induced "hypogranular" cerebella (Woodward et al., 1974; Crepel and Delhaye-Bouchaud, 1979; Bravin et al., 1995; Sugihara et al., 2000) revealed that the presence of intact granule cells, normal parallel fiber-Purkinje cell synapses, and activity all play a role in climbing fiber synapse elimination.

The process of fiber elimination is mediated by several molecules including metabotropic glutamate receptor mGluR1, PLC $\beta 4, \mathrm{Ca}(\mathrm{v}) 2.1 \mathrm{P} / \mathrm{Q}$-type $\mathrm{Ca}^{2+}$ channel, glutamate receptor Glur\$2, precerebellin (or Cbln1), and the GABA synthesizing enzyme GAD67 (Kano et al., 1995, 1997, 1998; Kashiwabuchi et al., 1995; Offermanns et al., 1997; Sugihara et al., 1999; Ichikawa et al., 2002; Miyazaki et al., 2004, 2010; Hirai et al., 2005; Uemura et al., 2007; Hashimoto et al., 2011; Nakayama et al., 2012; Uesaka et al., 2012). Mutations that alter the function of these proteins cause severe defects in climbing fiber synapse development and elimination (Kano et al., 1995, 1997, 1998; Kashiwabuchi et al., 1995; Offermanns et al., 1997; Sugihara et al., 1999; Ichikawa et al., 2002; Miyazaki et al., 2004, 2010; Hirai et al., 2005; Uemura et al., 2007; Hashimoto et al., 2011; Nakayama et al., 2012; Uesaka et al., 2012). Interestingly, Kano and colleagues developed an organotypic co-culture preparation to recapitulate in vivo climbing fiber remodeling and with this system identified neuroligin-2 as a key player of climbing fiber elimination in Purkinje cells (Uesaka et al., 2012). Thus, synaptogenesis in the olivocerebellar projection starts relatively early during brain circuit formation, occurs over a protracted period of time, and requires both genetic control and neural activity (Chedotal and Sotelo, 1992; Sotelo, 2004). However, it is not clear whether developmental remodeling plays a role in generating climbing fiber compartments: although one can imagine that the precise zonal boundaries emerge as supernumerary axons are pruned away.

\section{PLASTICITY OF OLIVOCEREBELLAR ZONE CONNECTIVITY}

In contrast to the adult central nervous system which has a limited capacity for axonal regeneration, the immature central nervous system is capable of some axonal regrowth (Nicholls and Saunders, 1996). However, regrowth during development frequently occurs through an alternative pathway that is distinct from the normal one. The olivocerebellar pathway is an excellent example of a system in which regrowth establishes a new pathway. Various groups have used the pedunculotomy approach to stimulate transcommissural olivocerebellar reinnervation to determine the temporal properties of afferent-target interactions during development (Angaut et al., 1985; Sherrard et al., 1986; Zagrebelsky et al., 1997; Sugihara et al., 2003; Dixon et al., 2005; Willson et al., 2007). Following unilateral early postnatal transection of an inferior cerebellar peduncle (which carries the climbing fibers), the contralateral inferior olive degenerates and new axons, arising from the remaining inferior olive, grow into the denervated hemicerebellum (Zagrebelsky et al., 1997). The innervation of these transcommissural axons precisely aligns with Purkinje cell expression zones and mirrors the distribution of the "unaltered" projections on the intact side (Zagrebelsky et al., 1997). Sugihara and colleagues (2003) have shown that the newly formed projections develop normal climbing fiber arborizations and form functional synapses onto Purkinje cells. Remarkably, olivocerebellar reinnervation can compensate for motor deficits (Dixon et al., 2005) and rescue the cerebellums influence over spatial learning (Willson et al., 2007). Similar to what might occur during normal development, reinnervation may be regulated by position-dependent cues that mediate the precise connectivity between climbing fibers and Purkinje cells (Dixon and Sherrard, 2006; Willson et al., 2008).

\section{NOVEL TOOLS TO STUDY OLIVOCEREBELLAR DEVELOPMENT, CONNECTIVITY, AND FUNCTION}

Neuronal tracing using viruses and genetically encoded fluorescent reporters are now widely used for unraveling circuit connectivity (Wickersham et al., 2007; Marshel et al., 2010; Wall et al., 2010). Retrograde transneuronal infection of rabies virus reveals the organization of multi-synaptic neuronal networks (Coulon et al., 1989; Ugolini, 1995; Kelly and Strick, 2000; Graf et al., 2002). Genetically modified viruses have also allowed control over which cells are initially infected, extent of viral spread, and direction of the spread (Callaway, 2008). Recently, the use of a deletion-mutant rabies virus allowed the spread of the virus to be restricted to monosynaptic connections for selectively revealing first-order presynaptic neurons (Wickersham et al., 2007, 2010; Marshel et al., 2010; Rancz et al., 2011). Using the rabies virus tracing approach, communication networks between the cerebral cortex, basal ganglia, and cerebellum have been resolved (Kelly and Strick, 2003; Bostan et al., 2010; Coffman et al., 2011; Suzuki et al., 2012). More recently, Ruigrok and colleagues also used viral tracing to show that cerebrocerebellar connectivity respects cerebellar zonal organization (Suzuki et al., 2012). Combining viral tracing with transgenic targeting of recombinant viruses (Weible et al., 2010) will allow for unparalleled resolution of circuit topography in the olivocerebellar pathway.

In the past, lesioning, electrical stimulation, and chemical activation/deactivation have unveiled essential functions of the cerebellum and inferior olive (Llinas et al., 1975; McCormick and Thompson, 1984; Bradley et al., 1991; O’Hearn et al., 1993; O'Hearn and Molliver, 1993; Willson et al., 2007; Pijpers et al., 2008; Strick et al., 2009; Horn et al., 2010; Cerminara and Apps, 2011). However, these manipulations are limited by the lack of cell type specificity and/or the by the tissue damage that occurs. Optogenetics methods offer an ideal solution to these shortcomings as they provide an avenue for targeting induced 
neural activity to specific cells in vivo, without damaging the circuit (Deisseroth et al., 2006; Zhang et al., 2006; Hira et al., 2009; Tsubota et al., 2011). These light-activated ion channels, which include channelrhodopsin-2 (ChR2) and halorhodopsin (eNpHR), have fast temporal kinetics to efficiently activate or inhibit the firing of action potentials (Boyden et al., 2005; Zhang et al., 2006; Adamantidis et al., 2007; Arenkiel et al., 2007; Abbott et al., 2009). Importantly, by using cell type specific promoters one can drive the expression of these light-responsive proteins in selective neuronal populations (e.g., using the L7/Pcp2 Purkinje cell specific promoter; Oberdick et al., 1990). Indeed, a recent study used L7/Pcp2-Cre mice to target ChR2 and eNpHR expression to examine the role of Purkinje cells in controlling cardiovascular function (Tsubota et al., 2011). It will now be interesting to develop optogenetic methods for manipulating neuronal activity within specific inferior olivary nuclei in order to determine the contribution of olivocerebellar zones to motor and nonmotor functions in vivo.

\section{SUMMARY}

It is well established that the cerebellum is divided into a complex map of functional zones. Much progress has been made in delineating the zonal topography between the inferior olivary nucleus,

\section{REFERENCES}

Abbott, S. B., Stornetta, R. L., Socolovsky, C. S., West, G. H., and Guyenet, P. G. (2009). Photostimulation of channelrhodopsin-2 expressing ventrolateral medullary neurons increases sympathetic nerve activity and blood pressure in rats. J. Physiol. 587, 5613-5631.

Adamantidis, A. R., Zhang, F., Aravanis, A. M., Deisseroth, K., and de Lecea, L. (2007). Neural substrates of awakening probed with optogenetic control of hypocretin neurons. Nature 450, 420-424.

Ahn, A. H., Dziennis, S., Hawkes, R., and Herrup, K. (1994). The cloning of zebrin II reveals its identity with aldolase C. Development 120, 2081-2090.

Allen-Sharpley, M. R., and Cramer, K. S. (2012). Coordinated Ephephrin signaling guides migration and axon targeting in the avian auditory system. Neural Dev. 7:29. doi: 10.1186/1749-8104-7-29

Altman, J., and Bayer, S. A. (1987). Development of the precerebellar nuclei in the rat: IV. The anterior precerebellar extramural migratory stream and the nucleus reticularis tegmenti pontis and the basal pontine gray. J. Comp. Neurol. 257, 529-552.

Altman, J. B. S. (1997). Development of the Cerebellar System in Relation to its Evolution, Structure, and Functions. New York, NY: CRC.
Angaut, P., Alvarado-Mallart, R. M., and Sotelo, C. (1985). Compensatory climbing fiber innervation after unilateral pedunculotomy in the newborn rat: origin and topographic organization. J. Comp. Neurol. 236, 161-178.

Apps, R., and Hawkes, R. (2009). Cerebellar cortical organization: a one-map hypothesis. Nat. Rev. Neurosci. 10, 670-681.

Arenkiel, B. R., Peca, J., Davison, I. G., Feliciano, C., Deisseroth, K., Augustine, G. J., et al. (2007). In vivo light-induced activation of neural circuitry in transgenic mice expressing channelrhodopsin-2. Neuron 54 , 205-218.

Armstrong, C. L., and Hawkes, R. (2000). Pattern formation in the cerebellar cortex. Biochem. Cell Biol. $78,551-562$.

Armstrong, C. L., Krueger-Naug, A. M., Currie, R. W., and Hawkes, R. (2000). Constitutive expression of the $25-\mathrm{kDa}$ heat shock protein Hsp25 reveals novel parasagittal bands of purkinje cells in the adult mouse cerebellar cortex. J. Comp. Neurol. 416, 383-397.

Armstrong, D. M., Harvey, R. J., and Schild, R. F. (1974). Topographical localization in the olivo-cerebellar projection: an electrophysiological study in the cat. J. Comp. Neurol. 154, 287-302.

Arsenio Nunes, M. L., and Sotelo, C. (1985). Development of the spinocerebellar system in the

cerebellar cortex, and the cerebellar nuclei. However, there are several important questions that remain unanswered. For example: (1) Are the olivocerebellar cells that project to each cerebellar zone born at different times and/or are they derived from different genetic lineages? (2) What are the molecular mechanisms that guide olivocerebellar projections into zonal compartments? and (3) What behaviors are encoded into each zone? In future studies, it will be interesting to combine modern anatomical tracing techniques with high-resolution imaging, sophisticated genetic approaches and electrophysiology to answer such questions.

\section{ACKNOWLEDGMENTS}

We would like to thank Lionel D. Vázquez-Figueroa (SMART Program student, Baylor college of Medicine) for his contribution to the cerebellar circuitry schematic. All animal work was carried out under an approved IACUC animal protocol at Baylor College of Medicine (Houston, TX). Roy V. Sillitoe is supported by the Caroline Wiess Law Fund for Research in Molecular Medicine, a BCM IDDRC Project Development Award, and start-up funds from Baylor College of Medicine and Texas Children's Hospital (Houston, TX). This work was also supported by BCM IDDRC Grant Number 5P30HD024064 from the Eunice Kennedy Shriver National Institute of Child Health and Human Development.

postnatal rat. J. Comp. Neurol. 237, 291-306.

Backer, S., Hidalgo-Sanchez, M., Offner, N., Portales-Casamar, E., Debant, A., Fort, P., et al. (2007). Trio controls the mature organization of neuronal clusters in the hindbrain. J. Neurosci. 27, 10323-10332.

Backer, S., Sakurai, T., Grumet, M., Sotelo, C., and Bloch-Gallego, E. (2002). Nr-CAM and TAG-1 are expressed in distinct populations of developing precerebellar and cerebellar neurons. Neuroscience 113, 743-748.

Belluardo, N., Mudo, G., TrovatoSalinaro, A., Le Gurun, S., Charollais, A., Serre-Beinier, V., et al. (2000). Expression of connexin36 in the adult and developing rat brain. Brain Res. 865, 121-138.

Blenkinsop, T. A., and Lang, E. J. (2006). Block of inferior olive gap junctional coupling decreases Purkinje cell complex spike synchrony and rhythmicity. J. Neurosci. 26, 1739-1748.

Bloch-Gallego, E., Ezan, F., TessierLavigne, M., and Sotelo, C. (1999). Floor plate and netrin-1 are involved in the migration and survival of inferior olivary neurons. J. Neurosci. 19, 4407-4420.

Bosman, L. W., Takechi, H., Hartmann, J., Eilers, J., and Konnerth, A. (2008). Homosynaptic longterm synaptic potentiation of the "winner" climbing fiber synapse in developing Purkinje cells. J. Neurosci. 28, 798-807.

Bostan, A. C., Dum, R. P., and Strick, P. L. (2010). The basal ganglia communicate with the cerebellum. Proc. Natl. Acad. Sci. U.S.A. 107, 8452-8456.

Bourrat, F., and Sotelo, C. (1988). Migratory pathways and neuritic differentiation of inferior olivary neurons in the rat embryo. Axonal tracing study using the in vitro slab technique. Brain Res. 467, 19-37.

Bourrat, F., and Sotelo, C. (1990a). Early development of the rat precerebellar system: migratory routes, selective aggregation and neuritic differentiation of the inferior olive and lateral reticular nucleus neurons. An overview. Arch. Ital. Biol. 128, 151-170.

Bourrat, F., and Sotelo, C. (1990b). Migratory pathways and selective aggregation of the lateral reticular neurons in the rat embryo: a horseradish peroxidase in vitro study, with special reference to migration patterns of the precerebellar nuclei. J. Comp. Neurol. 294, 1-13.

Bourrat, F., and Sotelo, C. (1991). Relationships between neuronal birthdates and cytoarchitecture in the rat inferior olivary complex. J. Comp. Neurol. 313, 509-521.

Boyden, E. S., Zhang, F., Bamberg, E., Nagel, G., and Deisseroth, K. (2005). Millisecond-timescale, genetically targeted optical control 
of neural activity. Nat. Neurosci. 8, 1263-1268.

Bozza, T., Feinstein, P., Zheng, C., and Mombaerts, P. (2002). Odorant receptor expression defines functional units in the mouse olfactory system. J. Neurosci. 22, 3033-3043.

Bradley, D. J., Ghelarducci, B., and Spyer, K. M. (1991). The role of the posterior cerebellar vermis in cardiovascular control. Neurosci. Res. 12, 45-56.

Bravin, M., Rossi, F., and Strata, P. (1995). Different climbing fibres innervate separate dendritic regions of the same Purkinje cell in hypogranular cerebellum. J. Comp. Neurol. 357, 395-407.

Brochu, G., Maler, L., and Hawkes, R. (1990). Zebrin II: a polypeptide antigen expressed selectively by Purkinje cells reveals compartments in rat and fish cerebellum. J. Comp. Neurol. 291, 538-552.

Cajal, R. Y. (1911). Histologie $d u$ Systeme Nerveux de l'homme et des Vertebres. Vol. II. Paris: Maloine.

Callaway, E. M. (2008). Transneuronal circuit tracing with neurotropic viruses. Curr. Opin. Neurobiol. 18, 617-623.

Cang, J., Niell, C. M., Liu, X., Pfeiffenberger, C., Feldheim, D. A., and Stryker, M. P. (2008a). Selective disruption of one Cartesian axis of cortical maps and receptive fields by deficiency in ephrin-As and structured activity. Neuron 57, 511-523.

Cang, J., Wang, L., Stryker, M. P., and Feldheim, D. A. (2008b). Roles of ephrin-as and structured activity in the development of functional maps in the superior colliculus. J. Neurosci. 28, 11015-11023.

Causeret, F., Danne, F., Ezan, F., Sotelo, C., and Bloch-Gallego, E. (2002). Slit antagonizes netrin-1 attractive effects during the migration of inferior olivary neurons. Dev. Biol. 246, 429-440.

Cerminara, N. L. (2010). Cerebellar modules: individual or composite entities? J. Neurosci. 30, 16065-16067.

Cerminara, N. L., and Apps, R. (2011). Behavioural significance of cerebellar modules. Cerebellum 10, 484-494.

Chedotal, A., Pourquie, O., Ezan, F., San Clemente, H., and Sotelo, C. (1996). BEN as a presumptive target recognition molecule during the development of the olivocerebellar system. J. Neurosci. 16, 3296-3310.

Chedotal, A., and Sotelo, C. (1992). Early development of olivocerebellar projections in the fetal rat using
CGRP immunocytochemistry. Eur. J. Neurosci. 4, 1159-1179.

Chedotal, A., and Sotelo, C. (1993). The 'creeper stage' in cerebellar climbing fiber synaptogenesis precedes the 'pericellular nest'ultrastructural evidence with parvalbumin immunocytochemistry. Brain Res. Dev. Brain Res. 76, 207-220.

Chen, L., Bao, S., Lockard, J. M., Kim, J. K., and Thompson, R. F. (1996). Impaired classical eyeblink conditioning in cerebellar-lesioned and Purkinje cell degeneration (pcd) mutant mice. J. Neurosci. 16, 2829-2838.

Chockkan, V., and Hawkes, R. (1994). Functional and antigenic maps in the rat cerebellum: zebrin compartmentation and vibrissal receptive fields in lobule IXa. J. Comp. Neurol. 345, 33-45.

Coffman, K. A., Dum, R. P., and Strick, P. L. (2011). Cerebellar vermis is a target of projections from the motor areas in the cerebral cortex. Proc. Natl. Acad. Sci. U.S.A. 108, 16068-16073.

Coulon, P., Derbin, C., Kucera, P., Lafay, F., Prehaud, C., and Flamand, A. (1989). Invasion of the peripheral nervous systems of adult mice by the CVS strain of rabies virus and its avirulent derivative AvO1. J. Virol. 63, 3550-3554.

Crepel, F., and Delhaye-Bouchaud, N. (1979). Distribution of climbing fibres on cerebellar Purkinje cells in X-irradiated rats. An electrophysiological study. J. Physiol. 290, 97-112.

Crepel, F., Delhaye-Bouchaud, N., Guastavino, J. M., and Sampaio, I. (1980). Multiple innervation of cerebellar Purkinje cells by climbing fibres in staggerer mutant mouse. Nature 283, 483-484.

Crepel, F., and Mariani, J. (1976). Multiple innervation of Purkinje cells by climbing fibers in the cerebellum of the weaver mutant mouse. J. Neurobiol. 7, 579-582.

Crepel, F., Mariani, J., and DelhayeBouchaud, N. (1976). Evidence for a multiple innervation of Purkinje cells by climbing fibers in the immature rat cerebellum. J. Neurobiol. 7, 567-578.

Cummings, S. L., Young, W. S. 3rd., Bishop, G. A., De Souza, E. B., and King, J. S. (1989). Distribution of corticotropin-releasing factor in the cerebellum and precerebellar nuclei of the opossum: a study utilizing immunohistochemistry, in situ hybridization histochemistry, and receptor autoradiography. J. Comp. Neurol. 280, 501-521. de Diego, I., Kyriakopoulou, K., Karagogeos, D., and Wassef, M. (2002). Multiple influences on the migration of precerebellar neurons in the caudal medulla. Development 129, 297-306.

Degen, J., Meier, C., Van Der Giessen, R. S., Sohl, G., Petrasch-Parwez, E. Urschel, S., et al. (2004). Expression pattern of lacZ reporter gene representing connexin36 in transgenic mice. J. Comp. Neurol. 473, 511-525.

Dehnes, Y., Chaudhry, F. A. Ullensvang, K., Lehre, K. P., Storm-Mathisen, J., and Danbolt, N. C. (1998). The glutamate transporter EAAT4 in rat cerebellar Purkinje cells: a glutamate-gated chloride channel concentrated near the synapse in parts of the dendritic membrane facing astroglia. J. Neurosci. 18, 3606-3619.

Deisseroth, K., Feng, G., Majewska, A. K., Miesenbock, G., Ting, A., and Schnitzer, M. J. (2006). Nextgeneration optical technologies for illuminating genetically targeted brain circuits. J. Neurosci. 26, 10380-10386.

Demilly, A., Reeber, S. L., Gebre, S. A., and Sillitoe, R. V. (2011). Neurofilament heavy chain expression reveals a unique parasagittal stripe topography in the mouse cerebellum. Cerebellum 10, 409-421.

Dixon, K. J., Hilber, W., Speare, S., Willson, M. L., Bower, A. J., and Sherrard, R. M. (2005). Post-lesion transcommissural olivocerebellar reinnervation improves motor function following unilateral pedunculotomy in the neonatal rat. Exp. Neurol. 196, 254-265.

Dixon, K. J., and Sherrard, R. M. (2006). Brain-derived neurotrophic factor induces post-lesion transcommissural growth of olivary axons that develop normal climbing fibers on mature Purkinje cells. Exp. Neurol. 202, 44-56.

Ebner, T. J., Wang, X., Gao, W., Cramer, S. W., and Chen, G. (2012). Parasagittal zones in the cerebellar cortex differ in excitability, information processing, and synaptic plasticity. Cerebellum 11, 418-419.

Ekerot, C. F., and Larson, B. (1980). Termination in overlapping sagittal zones in cerebellar anterior lobe of mossy and climbing fiber paths activated from dorsal funiculus. Exp. Brain Res. 38, 163-172.

Errante, L., Tang, D., Gardon, M., Sekerkova, G., Mugnaini, E., and Shaw, G. (1998). The intermediate filament protein peripherin is a marker for cerebellar climbing fibres. J. Neurocytol. 27, 69-84.
Flanagan, J. G., and Vanderhaeghen, P. (1998). The ephrins and Eph receptors in neural development. Annu. Rev. Neurosci. 21, 309-345.

Friedman, G. C., and O'Leary, D. D. (1996). Retroviral misexpression of engrailed genes in the chick optic tectum perturbs the topographic targeting of retinal axons. J. Neurosci. 16, 5498-5509.

Fujita, H., Oh-Nishi, A., Obayashi, S., and Sugihara, I. (2010). Organization of the marmoset cerebellum in three-dimensional space: lobulation, aldolase C compartmentalization and axonal projection. J. Comp. Neurol. 518, 1764-1791.

Graf, W., Gerrits, N., Yatim-Dhiba, N., and Ugolini, G. (2002). Mapping the oculomotor system: the power of transneuronal labelling with rabies virus. Eur. J. Neurosci. 15, 1557-1562.

Graham, D. J., and Wylie, D. R. (2012). Zebrin-immunopositive and -immunonegative stripe pairs represent functional units in the pigeon vestibulocerebellum. J. Neurosci. 32, 12769-12779.

Hallem, J. S., Thompson, J. H., Gundappa-Sulur, G., Hawkes, R., Bjaalie, J. G., and Bower, J. M. (1999). Spatial correspondence between tactile projection patterns and the distribution of the antigenic Purkinje cell markers anti-zebrin I and anti-zebrin II in the cerebellar folium crus IIA of the rat. Neuroscience 93, 1083-1094.

Hashimoto, K., Ichikawa, R., Kitamura, K., Watanabe, M., and Kano, M. (2009). Translocation of a "winner" climbing fiber to the Purkinje cell dendrite and subsequent elimination of "losers" from the soma in developing cerebellum. Neuron 63, 106-118.

Hashimoto, K., and Kano, M. (2003). Functional differentiation of multiple climbing fiber inputs during synapse elimination in the developing cerebellum. Neuron 38, 785-796.

Hashimoto, K., and Kano, M. (2005). Postnatal development and synapse elimination of climbing fiber to Purkinje cell projection in the cerebellum. Neurosci. Res. 53, 221-228.

Hashimoto, K., Tsujita, M., Miyazaki, T., Kitamura, K., Yamazaki, M., Shin, H. S., et al. (2011). Postsynaptic P/Q-type Ca2+ channel in Purkinje cell mediates synaptic competition and elimination in developing cerebellum. Proc. Natl. Acad. Sci. U.S.A. 108, 9987-9992. 
Hashimoto, M., and Hibi, M. (2012). Development and evolution of cerebellar neural circuits. Dev. Growth Differ. 54, 373-389.

Hashimoto, M., Ito, R., Kitamura, N., Namba, K., and Hisano, Y. (2012). Epha4 controls the midline crossing and contralateral axonal projections of inferior olive neurons. J. Comp. Neurol. 520, 1702-1720.

Hashimoto, M., and Mikoshiba, K. (2003). Mediolateral compartmentalization of the cerebellum is determined on the "birth date" of Purkinje cells. J. Neurosci. 23, 11342-11351.

Hawkes, R., Colonnier, M., and Leclerc, N. (1985). Monoclonal antibodies reveal sagittal banding in the rodent cerebellar cortex. Brain Res. 333, 359-365.

Hawkes, R., and Herrup, K. (1995). Aldolase C/zebrin II and the regionalization of the cerebellum. J. Mol. Neurosci. 6, 147-158.

Hawkes, R., and Leclerc, N. (1987). Antigenic map of the rat cerebellar cortex: the distribution of parasagittal bands as revealed by monoclonal anti-Purkinje cell antibody mabQ113. J. Comp. Neurol. 256, 29-41.

Hidalgo-Sanchez, M., Backer, S., Puelles, L., and Bloch-Gallego, E. (2012). Origin and plasticity of the subdivisions of the inferior olivary complex. Dev. Biol. 371, 215-226.

Hira, R., Honkura, N., Noguchi, J., Maruyama, Y., Augustine, G. J., Kasai, H., et al. (2009). Transcranial optogenetic stimulation for functional mapping of the motor cortex. J. Neurosci. Methods 179, 258-263.

Hirai, H., Pang, Z., Bao, D., Miyazaki, T., Li, L., Miura, E., et al. (2005). Cbln1 is essential for synaptic integrity and plasticity in the cerebellum. Nat. Neurosci. 8, 1534-1541.

Hisano, S., Sawada, K., Kawano, M., Kanemoto, M., Xiong, G., Mogi, K., et al. (2002). Expression of inorganic phosphate/ vesicular glutamate transporters (BNPI/VGLUT1 and DNPI/VGLUT2) in the cerebellum and precerebellar nuclei of the rat. Brain Res. Mol. Brain Res. 107, 23-31.

Horn, K. M., Pong, M., and Gibson, A. R. (2010). Functional relations of cerebellar modules of the cat. J. Neurosci. 30, 9411-9423.

Hoshino, M., Nakamura, S., Mori, K., Kawauchi, T., Terao, M., Nishimura, Y. V., et al. (2005). Ptfla, a bHLH transcriptional gene, defines GABAergic neuronal fates in cerebellum. Neuron 47, 201-213.
Hubel, D. H., and Wiesel, T. N. (1979). Brain mechanisms of vision. Sci. Am. 241, 150-162.

Huffman, K. J., and Cramer, K. S. (2007). EphA4 misexpression alters tonotopic projections in the auditory brainstem. Dev. Neurobiol. 67, 1655-1668.

Ichikawa, R., Miyazaki, T., Kano, M., Hashikawa, T., Tatsumi, H., Sakimura, K., et al. (2002). Distal extension of climbing fiber territory and multiple innervation caused by aberrant wiring to adjacent spiny branchlets in cerebellar Purkinje cells lacking glutamate receptor delta 2. J. Neurosci. 22, 8487-8503.

Jaarsma, D., Ruigrok, T. J., Caffe, R., Cozzari, C., Levey, A. I., Mugnaini, E., et al. (1997). Cholinergic innervation and receptors in the cerebellum. Prog. Brain Res. 114, 67-96.

Johnston, A. (1989). The geometry of the topographic map in striate cortex. Vision Res. 29, 1493-1500.

Kano, M., and Hashimoto, K. (2009). Synapse elimination in the central nervous system. Curr. Opin. Neurobiol. 19, 154-161.

Kano, M., Hashimoto, K., Chen, C., Abeliovich, A., Aiba, A., Kurihara, H., et al. (1995). Impaired synapse elimination during cerebellar development in PKC gamma mutant mice. Cell 83, 1223-1231.

Kano, M., Hashimoto, K., Kurihara, H., Watanabe, M., Inoue, Y., Aiba, A., et al. (1997). Persistent multiple climbing fiber innervation of cerebellar Purkinje cells in mice lacking mGluR1. Neuron 18, 71-79.

Kano, M., Hashimoto, K., Watanabe, M., Kurihara, H., Offermanns, S., Jiang, H., et al. (1998). Phospholipase cbeta4 is specifically involved in climbing fiber synapse elimination in the developing cerebellum. Proc. Natl. Acad. Sci. U.S.A. 95, 15724-15729.

Karam, S. D., Burrows, R. C., Logan, C., Koblar, S., Pasquale, E. B., and Bothwell, M. (2000). Eph receptors and ephrins in the developing chick cerebellum: relationship to sagittal patterning and granule cell migration. J. Neurosci. 20, 6488-6500.

Karam, S. D., Dottori, M., Ogawa, K., Henderson, J. T., Boyd, A. W., Pasquale, E. B., et al. (2002). EphA4 is not required for Purkinje cell compartmentation. Brain Res. Dev. Brain Res. 135, 29-38.

Kashiwabuchi, N., Ikeda, K., Araki, K., Hirano, T., Shibuki, K., Takayama, C., et al. (1995). Impairment of motor coordination, Purkinje cell synapse formation, and cerebellar long-term depression in GluR delta 2 mutant mice. Cell 81, 245-252.
Kelly, R. M., and Strick, P. L. (2000). Rabies as a transneuronal tracer of circuits in the central nervous system. J. Neurosci. Methods 103 63-71.

Kelly, R. M., and Strick, P. L. (2003). Cerebellar loops with motor cortex and prefrontal cortex of a nonhuman primate. J. Neurosci. 23, 8432-8444.

Landsberg, R. L., Awatramani, R. B., Hunter, N. L., Farago, A. F., DiPietrantonio, H. J., Rodriguez, C. I., et al. (2005). Hindbrain rhombic lip is comprised of discrete progenitor cell populations allocated by Pax6. Neuron 48, 933-947.

Lang, E. J., Sugihara, I., Welsh, J. P., and Llinas, R. (1999). Patterns of spontaneous purkinje cell complex spike activity in the awake rat. J. Neurosci. 19, 2728-2739.

Larouche, M., Che, P. M., and Hawkes, R. (2006). Neurogranin expression identifies a novel array of Purkinje cell parasagittal stripes during mouse cerebellar development. J. Comp. Neurol. 494, 215-227.

Larsell, O. (1952). The morphogenesis and adult pattern of the lobules and fissures of the cerebellum of the white rat. J. Comp. Neurol. 97, 281-356.

Leergaard, T. B., and Bjaalie, J. G (2007). Topography of the complete corticopontine projection: from experiments to principal Maps. Front. Neurosci. 1:1. doi: 10.3389/neuro.01.1.1.016.2007

Li, H., and Crair, M. C. (2011). How do barrels form in somatosensory cortex? Ann. N.Y. Acad. Sci. 1225, 119-129.

Llinas, R., and Sasaki, K. (1989). The functional organization of the olivocerebellar system as examined by multiple Purkinje cell recordings. Eur. J. Neurosci. 1, 587-602.

Llinas, R., Walton, K., Hillman, D. E. and Sotelo, C. (1975). Inferior olive: its role in motor learing. Science 190, 1230-1231.

Logan, C., Wizenmann, A., Drescher, U., Monschau, B., Bonhoeffer, F., and Lumsden, A. (1996). Rostral optic tectum acquires caudal characteristics following ectopic engrailed expression. Curr. Biol. 6 , 1006-1014.

Machold, R., and Fishell, G. (2005). Math1 is expressed in temporally discrete pools of cerebellar rhombic-lip neural progenitors. Neuron 48, 17-24.

Madisen, L., Zwingman, T. A., Sunkin, S. M., Wook Oh, S., Zariwala, H. A., Gu, H., et al. (2010). A robust and high-throughput Cre reporting and characterization system for the whole mouse brain. Nat. Neurosci. 13, 133-140.

Maklad, A., and Fritzsch, B. (2003). Partial segregation of posterior crista and saccular fibers to the nodulus and uvula of the cerebellum in mice, and its development. Brain Res. Dev. Brain Res. 140, 223-236.

Mariani, J., and Changeux, J. P. (1980). Multiple innervation of Purkinje cells by climbing fibers in the cerebellum of the adult staggerer mutant mouse. J. Neurobiol. 11, 41-50.

Mariani, J., and Changeux, J. P. (1981). Ontogenesis of olivocerebellar relationships. I. Studies by intracellular recordings of the multiple innervation of Purkinje cells by climbing fibers in the developing rat cerebellum. J. Neurosci. 1, 696-702.

Mariani, J., Crepel, F., Mikoshiba, K., Changeux, J. P., and Sotelo, C. (1977). Anatomical, physiological and biochemical studies of the cerebellum from Reeler mutant mouse. Philos. Trans. R. Soc. Lond. B Biol. Sci. 281, 1-28.

Marillat, V., Sabatier, C., Failli, V., Matsunaga, E., Sotelo, C., TessierLavigne, M., et al. (2004). The slit receptor Rig-1/Robo3 controls midline crossing by hindbrain precerebellar neurons and axons. Neuron 43, 69-79.

Marshel, J. H., Mori, T., Nielsen, K. J., and Callaway, E. M. (2010). Targeting single neuronal networks for gene expression and cell labeling in vivo. Neuron $67,562-574$.

Martin, E. I., Ressler, K. J., Jasnow, A. M., Dabrowska, J., Hazra, R., Rainnie, D. G., et al. (2010). A novel transgenic mouse for genetargeting within cells that express corticotropin-releasing factor. Biol. Psychiatry 67, 1212-1216.

Mason, C. A., Christakos, S., and Catalano, S. M. (1990). Early climbing fiber interactions with Purkinje cells in the postnatal mouse cerebellum. J. Comp. Neurol. 297, 77-90.

Mason, C. A., and Gregory, E. (1984). Postnatal maturation of cerebellar mossy and climbing fibers: transient expression of dual features on single axons. J. Neurosci. 4, 1715-1735.

McCormick, D. A., and Thompson, R. F. (1984). Cerebellum: essential involvement in the classically conditioned eyelid response. Science 223, 296-299.

Miyazaki, T., Hashimoto, K., Shin, H. S., Kano, M., and Watanabe, M. (2004). P/Q-type Ca2+ channel alpha1A regulates synaptic competition on developing cerebellar Purkinje cells. J. Neurosci. 24, 1734-1743 
Miyazaki, T., Yamasaki, M., Takeuchi, T., Sakimura, K., Mishina, M., and Watanabe, M. (2010). Ablation of glutamate receptor GluRdelta2 in adult Purkinje cells causes multiple innervation of climbing fibers by inducing aberrant invasion to parallel fiber innervation territory. J. Neurosci. 30, 15196-15209.

Morara, S., Marcotti, W., Provini, L., and Rosina, A. (1997). Neuropeptide, Y (NPY) expression is up-regulated in the rat inferior olive during development. Neuroreport 8, 3743-3747.

Morara, S., Rosina, A., and Provini, L. (1992). CGRP as a marker of the climbing fibers during the development of the cerebellum in the rat. Ann. N.Y. Acad. Sci. 657, 461-463.

Nakayama, H., Miyazaki, T., Kitamura, K., Hashimoto, K., Yanagawa, Y., Obata, K., et al. (2012). GABAergic inhibition regulates developmental synapse elimination in the cerebellum. Neuron 74, 384-396.

Namba, K., Sugihara, I., and Hashimoto, M. (2011). Close correlation between the birth date of Purkinje cells and the longitudinal compartmentalization of the mouse adult cerebellum. J. Comp. Neurol. 519, 2594-2614.

Neudert, F., Nuernberger, K. K., and Redies, C. (2008). Comparative analysis of cadherin expression and connectivity patterns in the cerebellar system of ferret and mouse. J. Comp. Neurol. 511, 736-752.

Nicholls, J., and Saunders, N. (1996). Regeneration of immature mammalian spinal cord after injury. Trends Neurosci. 19, 229-234.

Nichols, D. H., and Bruce, L. L. (2006). Migratory routes and fates of cells transcribing the Wnt-1 gene in the murine hindbrain. Dev. Dyn. 235, 285-300.

Nishida, K., Flanagan, J. G., and Nakamoto, M. (2002). Domainspecific olivocerebellar projection regulated by the EphA-ephrin-A interaction. Development 129, 5647-5658.

Nishiyama, H., Fukaya, M., Watanabe, M., and Linden, D. J. (2007). Axonal motility and its modulation by activity are branch-type specific in the intact adult cerebellum. Neuron 56, 472-487.

O'Hearn, E., Long, D. B., and Molliver, M. E. (1993). Ibogaine induces glial activation in parasagittal zones of the cerebellum. Neuroreport 4, 299-302.

O'Hearn, E., and Molliver, M. E. (1993). Degeneration of Purkinje cells in parasagittal zones of the cerebellar vermis after treatment with ibogaine or harmaline. Neuroscience 55, 303-310.

O'Leary, J. L., Inukai, J., and Smith, J. M. (1971). Histogenesis of the cerebellar climbing fiber in the rat. J. Comp. Neurol. 142, 377-391.

Oberdick, J., Smeyne, R. J., Mann, J. R., Zackson, S., and Morgan, J. I. (1990). A promoter that drives transgene expression in cerebellar Purkinje and retinal bipolar neurons. Science 248, 223-226.

Offermanns, S., Hashimoto, K., Watanabe, M., Sun, W., Kurihara, H., Thompson, R. F., et al. (1997). Impaired motor coordination and persistent multiple climbing fiber innervation of cerebellar Purkinje cells in mice lacking Galphaq. Proc. Natl. Acad. Sci. U.S.A. 94, 14089-14094.

Ozol, K., Hayden, J. M., Oberdick, J., and Hawkes, R. (1999). Transverse zones in the vermis of the mouse cerebellum. J. Comp. Neurol. 412, 95-111.

Pakan, J. M., and Wylie, D. R. (2008). Congruence of zebrin II expression and functional zones defined by climbing fiber topography in the flocculus. Neuroscience 157, 57-69.

Paradies, M. A., and Eisenman, L. M. (1993). Evidence of early topographic organization in the embryonic olivocerebellar projection: a model system for the study of pattern formation processes in the central nervous system. Dev. Dyn. 197, 125-145.

Paradies, M. A., Grishkat, H., Smeyne, R. J., Oberdick, J., Morgan, J. I., and Eisenman, L. M. (1996). Correspondence between L7lacZ-expressing Purkinje cells and labeled olivocerebellar fibers during late embryogenesis in the mouse. J. Comp. Neurol. 374, 451-466.

Pascual, M., Abasolo, I., MingoranceLe Meur, A., Martinez, A., Del Rio, J. A., Wright, C. V., et al. (2007). Cerebellar GABAergic progenitors adopt an external granule cell-like phenotype in the absence of Ptfla transcription factor expression. Proc. Natl. Acad. Sci. U.S.A. 104, 5193-5198.

Paukert, M., Huang, Y. H., Tanaka, K., Rothstein, J. D., and Bergles, D. E. (2010). Zones of enhanced glutamate release from climbing fibers in the mammalian cerebellum. J. Neurosci. 30, 7290-7299.

Pierce, E. T. (1973). Time of origin of neurons in the brain stem of the mouse. Prog. Brain Res. 40, 53-65.

Pijpers, A., Winkelman, B. H., Bronsing, R., and Ruigrok, T. J. (2008). Selective impairment of the cerebellar $\mathrm{C} 1$ module involved in rat hind limb control reduces step-dependent modulation of cutaneous reflexes. J. Neurosci. 28 , 2179-2189.

Rancz, E. A., Franks, K. M., Schwarz, M. K., Pichler, B., Schaefer, A. T., and Margrie, T. W. (2011) Transfection via whole-cell recording in vivo: bridging single-cell physiology, genetics and connectomics. Nat. Neurosi. 14 527-532.

Redies, C., Neudert, F., and Lin, J. (2011). Cadherins in cerebellar development: translation of embryonic patterning into mature functional compartmentalization. Cerebellum 10, 393-408.

Reeber, S. L., and Sillitoe, R. V. (2011). Patterned expression of a cocaineand amphetamine-regulated transcript peptide reveals complex circuit topography in the rodent cerebellar cortex. J. Comp. Neurol. 519, 1781-1796.

Rekling, J. C., Jensen, K. H., and Jahnsen, H. (2012). Spontaneous cluster activity in the inferior olivary nucleus in brainstem slices from postnatal mice. J. Physiol. 590, 1547-1562.

Rodriguez, C. I., and Dymecki, S. M. (2000). Origin of the precerebellar system. Neuron 27, 475-486.

Ruigrok, T. J. (2011). Ins and outs of cerebellar modules. Cerebellum 10, 464-474.

Sacchetti, B., Scelfo, B., and Strata, P. (2009). Cerebellum and emotional behavior. Neuroscience 162, 756-762.

Sarna, J. R., Marzban, H., Watanabe, M., and Hawkes, R. (2006). Complementary stripes of phospholipase Cbeta3 and Cbeta4 expression by Purkinje cell subsets in the mouse cerebellum. J. Comp. Neurol. 496, 303-313.

Sasaki, K., Bower, J. M., and Llinas, R. (1989). Multiple Purkinje cell recording in rodent cerebellar cortex. Eur. J. Neurosci. 1, 572-586.

Sawada, K., Fukui, Y., and Hawkes, R. (2008). Spatial distribution of corticotropin-releasing factor immunopositive climbing fibers in the mouse cerebellum: analysis by whole mount immunohistochemistry. Brain Res. 1222, 106-117.

Sawada, K., Sakata-Haga, H., Hisano, S., and Fukui, Y. (2001). Topological relationship between corticotropinreleasing factor-immunoreactive cerebellar afferents and tyrosine hydroxylase-immunoreactive Purkinje cells in a hereditary ataxic mutant, rolling mouse Nagoya. Neuroscience 102, 925-935.
Seoane, A., Apps, R., Balbuena, E., Herrero, L., and Llorens, J. (2005). Differential effects of trans-crotononitrile and 3acetylpyridine on inferior olive integrity and behavioural performance in the rat. Eur. J. Neurosci. 22, 880-894.

Sherrard, R. M., Bower, A. J., and Payne, J. N. (1986). Innervation of the adult rat cerebellar hemisphere by fibres from the ipsilateral inferior olive following unilateral neonatal pedunculotomy: an autoradiographic and retrograde fluorescent double-labelling study. Exp. Brain Res. 62, 411-421.

Sillitoe, R. V., Gopal, N., and Joyner, A. L. (2009). Embryonic origins of ZebrinII parasagittal stripes and establishment of topographic Purkinje cell projections. Neuroscience 162, 574-588.

Sillitoe, R. V., and Hawkes, R. (2002). Whole-mount immunohistochemistry: a high-throughput screen for patterning defects in the mouse cerebellum. J. Histochem. Cytochem. 50, 235-244.

Sillitoe, R. V., and Joyner, A. L. (2007). Morphology, molecular codes, and circuitry produce the threedimensional complexity of the cerebellum. Annu. Rev. Cell Dev. Biol. 23, 549-577.

Sillitoe, R. V., Marzban, H., Larouche, M., Zahedi, S., Affanni, J., and Hawkes, R. (2005). Conservation of the architecture of the anterior lobe vermis of the cerebellum across mammalian species. Prog. Brain Res. 148, 283-297.

Sillitoe, R. V., Vogel, M. W., and Joyner, A. L. (2010). Engrailed homeobox genes regulate establishment of the cerebellar afferent circuit map. J. Neurosci. 30, 10015-10024.

Soriano, P. (1999). Generalized lacZ expression with the ROSA26 Cre reporter strain. Nat. Genet. 21, 70-71.

Sotelo, C. (2004). Cellular and genetic regulation of the development of the cerebellar system. Prog. Neurobiol. 72, 295-339.

Sotelo, C., Bourrat, F., and Triller, A. (1984). Postnatal development of the inferior olivary complex in the rat. II. Topographic organization of the immature olivocerebellar projection. J. Comp. Neurol. 222, 177-199.

Sotelo, C., and Chedotal, A. (1997). Development of the olivocerebellar projection. Perspect. Dev. Neurobiol. 5, 57-67.

Sotelo, C., and Chedotal, A. (2005). Development of the olivocerebellar system: migration and formation 
of cerebellar maps. Prog. Brain Res. 148, 1-20.

Sotelo, C., and Wassef, M. (1991). Cerebellar development: afferent organization and Purkinje cell heterogeneity. Philos. Trans. R. Soc. Lond. B Biol. Sci. 331, 307-313.

Steinmayr, M., Andre, E., Conquet, F., Rondi-Reig, L., Delhaye-Bouchaud, N., Auclair, N., et al. (1998). staggerer phenotype in retinoid-related orphan receptor alpha-deficient mice. Proc. Natl. Acad. Sci. U.S.A. 95, 3960-3965.

Strata, P., Scelfo, B., and Sacchetti, B. (2011). Involvement of cerebellum in emotional behavior. Physiol. Res. 60(Suppl. 1), S39-S48.

Strick, P. L., Dum, R. P., and Fiez, J. A. (2009). Cerebellum and nonmotor function. Annu. Rev. Neurosci. 32, 413-434.

Sudarov, A., and Joyner, A. L. (2007). Cerebellum morphogenesis: the foliation pattern is orchestrated by multi-cellular anchoring centers. Neural Dev. 2:26. doi: 10.1186/1749-8104-2-26

Sudarov, A., Turnbull, R. K., Kim, E. J., Lebel-Potter, M., Guillemot, F., and Joyner, A. L. (2011). Ascll genetics reveals insights into cerebellum local circuit assembly. J. Neurosci. 31, 11055-11069.

Sugihara, I. (2005). Microzonal projection and climbing fiber remodeling in single olivocerebellar axons of newborn rats at postnatal days 4-7. J. Comp. Neurol. 487, 93-106.

Sugihara, I., Bailly, Y., and Mariani, J. (2000). Olivocerebellar climbing fibers in the granuloprival cerebellum: morphological study of individual axonal projections in the X-irradiated rat. J. Neurosci. 20, 3745-3760.

Sugihara, I., Fujita, H., Na, J., Quy, P. N., Li, B. Y., and Ikeda, D. (2009). Projection of reconstructed single Purkinje cell axons in relation to the cortical and nuclear aldolase $\mathrm{C}$ compartments of the rat cerebellum. J. Comp. Neurol. 512, 282-304.

Sugihara, I., Lang, E. J., and Llinas, R. (1995). Serotonin modulation of inferior olivary oscillations and synchronicity: a multiple-electrode study in the rat cerebellum. Eur. J. Neurosci. 7, 521-534.

Sugihara, I., Lohof, A. M., Letellier, M., Mariani, J., and Sherrard, R. M. (2003). Post-lesion transcommissural growth of olivary climbing fibres creates functional synaptic microzones. Eur. J. Neurosci. 18, 3027-3036.

Sugihara, I., and Quy, P. N. (2007). Identification of aldolase $\mathrm{C}$ compartments in the mouse cerebellar cortex by olivocerebellar labeling. J. Comp. Neurol. 500, 1076-1092.

Sugihara, I., and Shinoda, Y. (2004). Molecular, topographic, and functional organization of the cerebellar cortex: a study with combined aldolase $\mathrm{C}$ and olivocerebellar labeling. J. Neurosci. 24, 8771-8785.

Sugihara, I., and Shinoda, Y. (2007). Molecular, topographic, and functional organization of the cerebellar nuclei: analysis by three-dimensional mapping of the olivonuclear projection and aldolase C labeling. J. Neurosci. 27, 9696-9710.

Sugihara, I., Wu, H., and Shinoda, Y. (1999). Morphology of single olivocerebellar axons labeled with biotinylated dextran amine in the rat. J. Comp. Neurol. 414, 131-148.

Suzuki, L., Coulon, P., SabelGoedknegt, E. H., and Ruigrok, T. J. (2012). Organization of cerebral projections to identified cerebellar zones in the posterior cerebellum of the rat. J. Neurosci. 32, 10854-10869.

Suzuki, S. C., Inoue, T., Kimura, Y., Tanaka, T., and Takeichi, M. (1997). Neuronal circuits are subdivided by differential expression of typeII classic cadherins in postnatal mouse brains. Mol. Cell. Neurosci. 9, 433-447.

Tanahira, C., Higo, S., Watanabe, K., Tomioka, R., Ebihara, S., Kaneko, T., et al. (2009). Parvalbumin neurons in the forebrain as revealed by parvalbumin-Cre transgenic mice. Neurosci. Res. 63, 213-223.

Taniguchi, H., He, M., Wu, P., Kim, S., Paik, R., Sugino, K., et al. (2011). A resource of Cre driver lines for genetic targeting of GABAergic neurons in cerebral cortex. Neuron 71, 995-1013.

Terada, N., Banno, Y., Ohno, N., Fujii, Y., Murate, T., Sarna, J. R., et al. (2004). Compartmentation of the mouse cerebellar cortex by sphingosine kinase. J. Comp. Neurol. 469, 119-127.

Tsubota, T., Ohashi, Y., Tamura, K., Sato, A., and Miyashita, Y. (2011). Optogenetic manipulation of cerebellar Purkinje cell activity in vivo. PLoS ONE 6:e22400. doi: 10.1371/journal.pone.0022400

Uemura, T., Kakizawa, S., Yamasaki, M., Sakimura, K., Watanabe, M., Iino, M., et al. (2007). Regulation of long-term depression and climbing fiber territory by glutamate receptor delta2 at parallel fiber synapses through its C-terminal domain in cerebellar Purkinje cells. J. Neurosci. 27, 12096-12108.
Uesaka, N., Mikuni, T., Hashimoto, K., Hirai, H., Sakimura, K., and Kano, M. (2012). Organotypic coculture preparation for the study of developmental synapse elimination in mammalian brain. J. Neurosci. 32, 11657-11670.

Ueyama, T., Houtani, T., Nakagawa, H., Baba, K., Ikeda, M., Yamashita, T., et al. (1994). A subpopulation of olivocerebellar projection neurons express neuropeptide Y. Brain Res. 634, 353-357.

Ugolini, G. (1995). Specificity of rabies virus as a transneuronal tracer of motor networks: transfer from hypoglossal motoneurons to connected second-order and higher order central nervous system cell groups. J. Comp. Neurol. 356, 457-480.

Van Der Giessen, R. S., Maxeiner, S., French, P. J., Willecke, K., and De Zeeuw, C. I. (2006). Spatiotemporal distribution of Connexin45 in the olivocerebellar system. J. Comp. Neurol. 495, 173-184.

Voogd, J., Pardoe, J., Ruigrok, T. J., and Apps, R. (2003). The distribution of climbing and mossy fiber collateral branches from the copula pyramidis and the paramedian lobule: congruence of climbing fiber cortical zones and the pattern of zebrin banding within the rat cerebellum. J. Neurosci. 23, 4645-4656.

Voogd, J., and Ruigrok, T. J. (2004) The organization of the corticonuclear and olivocerebellar climbing fiber projections to the rat cerebellar vermis: the congruence of projection zones and the zebrin pattern. J. Neurocytol. 33, 5-21.

Wadiche, J. I., and Jahr, C. E. (2005). Patterned expression of Purkinje cell glutamate transporters controls synaptic plasticity. Nat. Neurosci. 8, 1329-1334.

Wall, N. R., Wickersham, I. R., Cetin, A., De La Parra, M., and Callaway, E. M. (2010). Monosynaptic circuit tracing in vivo through Cre-dependent targeting and complementation of modified rabies virus. Proc. Natl. Acad. Sci. U.S.A. 107, 21848-21853.

Wang, V. Y., Rose, M. F., and Zoghbi, H. Y. (2005). Mathl expression redefines the rhombic lip derivatives and reveals novel lineages within the brainstem and cerebellum. Neuron 48, 31-43.

Wassef, M., Chedotal, A., Cholley, B., Thomasset, M., Heizmann, C. W., and Sotelo, C. (1992). Development of the olivocerebellar projection in the rat: I. Transient biochemical compartmentation of the inferior olive. J. Comp. Neurol. 323, 519-536.

Watanabe, M., and Kano, M. (2011). Climbing fiber synapse elimination in cerebellar Purkinje cells. Eur. J. Neurosci. 34, 1697-1710.

Watanabe, Y., Kinoshita, K., Koguchi, A., and Yamamura, M. (1997). A new method for evaluation of motor deficits in 3-acetylpyridinetreated rats. J. Neurosci. Methods 77, 25-29.

Watt, A. J., Cuntz, H., Mori, M., Nusser, Z., Sjostrom, P. J., and Hausser, M. (2009). Traveling waves in developing cerebellar cortex mediated by asymmetrical Purkinje cell connectivity. Nat. Neurosci. 12, 463-473.

Weible, A. P., Schwarcz, L., Wickersham, I. R., Deblander, L., Wu, H., Callaway, E. M., et al. (2010). Transgenic targeting of recombinant rabies virus reveals monosynaptic connectivity of specific neurons. J. Neurosci. 30, 16509-16513.

Weickert, S., Ray, A., Zoidl, G., and Dermietzel, R. (2005). Expression of neural connexins and pannexin 1 in the hippocampus and inferior olive: a quantitative approach. Brain Res. Mol. Brain Res. 133, 102-109.

White, J. J., Reeber, S. L., Hawkes, R., and Sillitoe, R. V. (2012). Wholemount immunohistochemistry for revealing complex brain topography. J. Vis. Exp. 62:e4042. doi: 10.3791/4042

White, J. J., and Sillitoe, R. V. (2013). Development of the cerebellum: from gene expression patterns to circuit maps. WIREs Dev. Biol. 2, 149-164.

Wickersham, I. R., Lyon, D. C., Barnard, R. J., Mori, T., Finke, S., Conzelmann, K. K., et al. (2007). Monosynaptic restriction of transsynaptic tracing from single, genetically targeted neurons. Neuron 53, 639-647.

Wickersham, I. R., Sullivan, H. A., and Seung, H. S. (2010). Production of glycoprotein-deleted rabies viruses for monosynaptic tracing and highlevel gene expression in neurons. Nat. Protoc. 5, 595-606.

Willson, M. L., Bower, A. J., and Sherrard, R. M. (2007). Developmental neural plasticity and its cognitive benefits: olivocerebellar reinnervation compensates for spatial function in the cerebellum. Eur. J. Neurosci. 25, 1475-1483.

Willson, M. L., McElnea, C., Mariani, J., Lohof, A. M., and Sherrard, R. 
M. (2008). BDNF increases homotypic olivocerebellar reinnervation and associated fine motor and cognitive skill. Brain 131, 1099-1112.

Wilson, S. L., Kalinovsky, A., Orvis, G. D., and Joyner, A. L. (2011). Spatially restricted and developmentally dynamic expression of engrailed genes in multiple cerebellar cell types. Cerebellum 10, 356-372.

Wise, A. K., Cerminara, N. L., MarpleHorvat, D. E., and Apps, R. (2010). Mechanisms of synchronous activity in cerebellar Purkinje cells. J. Physiol. 588, 2373-2390.

Woodward, D. J., Hoffer, B. J., and Altman, J. (1974). Physiological and pharmacological properties of Purkinje cells in rat cerebellum degranulated by postnatal x-irradiation. J. Neurobiol. 5, 283-304.

Woodward, D. J., Hoffer, B. J., and Lapham, L. W. (1969). Postnatal development of electrical and enzyme histochemical activity in
Purkinje cells. Exp. Neurol. 23, 120-139.

Xiang, M., Gan, L., Zhou, L., Klein, W. H., and Nathans, J. (1996). Targeted deletion of the mouse POU domain gene Brn-3a causes selective loss of neurons in the brainstem and trigeminal ganglion, uncoordinated limb movement, and impaired suckling. Proc. Natl. Acad. Sci. U.S.A. 93, 11950-11955.

Yamada, M., Terao, M., Terashima, T., Fujiyama, T., Kawaguchi, Y., Nabeshima, Y., et al. (2007). Origin of climbing fiber neurons and their developmental dependence on Ptfla. J. Neurosci. 27, 10924-10934.

Yamano, M., and Tohyama, M. (1994). Distribution of corticotropinreleasing factor and calcitonin gene-related peptide in the developing mouse cerebellum. Neurosci. Res. 19, 387-396.

Yan, X. X., and Garey, L. J. (1996). Calretinin immunoreactivity in the monkey and cat cerebellum: cellular localisation and modular distribution. J. Hirnforsch. 37, 409-419.

Zagrebelsky, M., Strata, P., Hawkes, R., and Rossi, F. (1997). Reestablishment of the olivocerebellar projection map by compensatory transcommissural reinnervation following unilateral transection of the inferior cerebellar peduncle in the newborn rat. J. Comp. Neurol. 379, 283-299.

Zappala, A., Parenti, R., La Delia, F., Cicirata, V., and Cicirata, F. (2010). Expression of connexin57 in mouse development and in harmalinetremor model. Neuroscience 171, $1-11$.

Zhang, F., Wang, L. P., Boyden, E. S., and Deisseroth, K. (2006). Channelrhodopsin-2 and optical control of excitable cells. Nat. Methods 3, 785-792.

Zhu, Y., and Guthrie, S. (2002). Expression of the ETS transcription factor ER81 in the developing chick and mouse hindbrain. Dev. Dyn. 225, 365-368.
Conflict of Interest Statement: The authors declare that the research was conducted in the absence of any commercial or financial relationships that could be construed as a potential conflict of interest.

Received: 28 September 2012; accepted: 12 December 2012; published online: 02 January 2013.

Citation: Reeber SL, White JJ, GeorgeJones NA and Sillitoe RV (2013) Architecture and development of olivocerebellar circuit topography. Front. Neural Circuits 6:115. doi: 10.3389/ fncir.2012.00115

Copyright (C) 2013 Reeber, White, George-Jones and Sillitoe. This is an open-access article distributed under the terms of the Creative Commons Attribution License, which permits use, distribution and reproduction in other forums, provided the original authors and source are credited and subject to any copyright notices concerning any third-party graphics etc. 